\title{
Recent Developments in Microbe- Plant-Based Bioremediation for Tackling Heavy Metal-Polluted Soils
}

\author{
Lala Saha ${ }^{1 \dagger}$, Jaya Tiwari ${ }^{2 \dagger}$, Kuldeep Bauddh ${ }^{1 *}$ and Ying $\mathrm{Ma}^{3 *}$ \\ ${ }^{1}$ Department of Environmental Sciences, Central University of Jharkhand, Ranchi, India, ${ }^{2}$ Department of Community \\ Medicine and School of Public Health, PGIMER, Chandigarh, India, ${ }^{3}$ College of Resources and Environment, Southwest \\ University, Chongqing, China
}

\section{OPEN ACCESS}

Edited by:

Obulisamy Parthiba Karthikeyan, University of Houston, United States

Reviewed by:

Muhammad Rizwan, Nuclear Institute of Agriculture, Pakistan

Rajeev Pratap Singh, Banaras Hindu University, India Ignacio D Rodriguez-Llorente,

Sevilla University, Spain

*Correspondence:

Kuldeep Bauddh

kuldeep.bauddh@cuj.ac.in

Ying Ma

cathymaying@hotmail.com

tThese authors have contributed equally to this work

Specialty section:

This article was submitted to

Microbiotechnology,

a section of the journal

Frontiers in Microbiology

Received: 28 June 2021 Accepted: 24 November 2021 Published: 23 December 2021

Citation:

Saha L, Tiwari J, Bauddh K and Ma Y (2021) Recent Developments in Microbe-Plant-Based Bioremediation for Tackling Heavy Metal-Polluted
Soil contamination with heavy metals (HMs) is a serious concern for the developing world due to its non-biodegradability and significant potential to damage the ecosystem and associated services. Rapid industrialization and activities such as mining, manufacturing, and construction are generating a huge quantity of toxic waste which causes environmental hazards. There are various traditional physicochemical techniques such as electroremediation, immobilization, stabilization, and chemical reduction to clean the contaminants from the soil. However, these methods require high energy, trained manpower, and hazardous chemicals make these techniques costly and non-environment friendly. Bioremediation, which includes microorganism-based, plant-based, microorganism-plant associated, and other innovative methods, is employed to restore the contaminated soils. This review covers some new aspects and dimensions of bioremediation of heavy metalpolluted soils. The bioremediation potential of bacteria and fungi individually and in association with plants has been reviewed and critically examined. It is reported that microbes such as Pseudomonas spp., Bacillus spp., and Aspergillus spp., have high metal tolerance, and bioremediation potential up to $98 \%$ both individually and when associated with plants such as Trifolium repens, Helianthus annuus, and Vallisneria denseserrulata. The mechanism of microbe's detoxification of metals depends upon various aspects which include the internal structure, cell surface properties of microorganisms, and the surrounding environmental conditions have been covered. Further, factors affecting the bioremediation efficiency and their possible solution, along with challenges and future prospects, are also discussed.

Keywords: bioremediation, beneficial microorganisms, heavy metals, phytoremediation, soil management

\section{INTRODUCTION}

With the onset of the twentieth century, human beings have witnessed advancement in technologies related to food production, health, infrastructure, transport, and communications. Such activities require a vast quantity of new materials and energies destroying natural environmental components and the production of huge quantities of wastes resulting in environmental degradation (Mani and Kumar, 2014). The presence of toxic metals and metalloids 
in the waste generated from the industrial, domestic, and agricultural sectors causes significant damages to the ecosystem and associated lives (Pourret et al., 2016; Goyal et al., 2020; Leong and Chang, 2020). The contaminants are highly mobile and soluble, thus possessing the capability to be bioaccumulated in the food chain and causing serious damage with increasing tropic levels (Petavratzi et al., 2005; Zerizghi et al., 2020). When these contaminants enter the human body, they can cause various life-threatening diseases such as cancer, kidney and bone diseases, cardiovascular diseases, hypertension, low birth weight, Alzheimer diseases, and atherosclerosis (Nawrot et al., 2006; Ahern et al., 2011; Bernhoft, 2012; Flora et al., 2012; Muszynska and Hanus-Fajerska, 2015; Lee et al., 2017). Metal accumulated in biological tissues is hard to remove due to its non-biodegradability, and it becomes a major concern to global health (Ayangbenro and Babalola, 2017). Metal contamination leads to the alteration in soil physicochemical and biological properties such as an increase in bulk density and soil $\mathrm{pH}$, as well as a decrease in soil fertility and water holding capacity, microbial diversity and soil enzyme activity (Wuana and Okieimen, 2011; Jin et al., 2019; Saha and Bauddh, 2020). They are also responsible for the alteration in microbial communities, leading to disturbing the proper function of the biogeochemical cycle and imbalance in the ecosystem (De Quadros et al., 2016; Feng et al., 2019). Heavy metals like As, $\mathrm{Hg}, \mathrm{Ni}, \mathrm{Cr}, \mathrm{Pb}$, and $\mathrm{Cu}$ can cause multiple indirect and direct effects on plant growth, such as chlorosis, necrosis, root injury, reduced carotenoid concentration, oxidative stress, inhibition of enzyme activities, osmotic imbalance, decreased photosynthetic activities, and imbalance of the nutrients (Lewis et al., 2001; Mascher et al., 2006; Shaibur et al., 2009; Yadav, 2010; Hasan et al., 2017; Sachan and Lal, 2017). Further, due to these environmental effects of metals, there are incessant efforts made to sustainably eliminate this toxic and excess amount of metals for stabilizing the ecosystem.

Various physicochemical techniques (such as extraction, immobilization, stabilization, coagulation, electrodialysis, vitrification, reverse osmosis, ion exchange, chemical reduction, evapotranspiration, and precipitation) have already been practicing to reduce metal contamination (Ali et al., 2013; Gupta and Kumar, 2017). However, these techniques are costly, require high energy, harsh chemicals with low removal efficiency, and can generate secondary environmental pollution (Tang et al., 2007; Acheampong et al., 2010; Ali et al., 2013; Gupta and Diwan, 2016; Suman et al., 2018). Therefore, there is a continuous demand for environmental friendly remediation methods that can be helpful to reduce its harmful effects on the environment.

Bioremediation is an ecologically sound technique that requires the use of green plants, microorganisms including fungi, bacteria, yeast, and algae or their enzymes to help the polluted sites return to their original states (Chakraborty et al., 2012; Mani and Kumar, 2014). The late $19^{\text {th }}$ century ascertained to be the golden period for bioremediation. With further improvement, the $20^{\text {th }}$ century marked the beginning of research in the field of microbial ecology, involving the identification and isolation of microbes that have the potential to degrade pollutants, e.g., Candidatus accumulibacter that is capable of accumulating excess amount of phosphorus as polyphosphates in their cells from the sewage treatment plants (Seviour et al., 2003). Later, the delineation of catabolic pathways to break pollutants, the genomic construction of recombinant microbes tailored to eliminate metals, and the application of molecular techniques to understand microbial activities have been explored (Siezen and Galardini, 2008; Ramos et al., 2011).

Soil microorganisms play an essential role in stabilizing soil macroaggregates by producing polysaccharides to maintain soil architectural patterns for plant productivity (Ghose, 2005). Such microorganisms including numerous species of bacteria, fungi, yeast, and algae contribute significantly to the decomposition and stabilization of inorganic and organic pollutants (Fulekar et al., 2012; Rahman et al., 2015; Leong and Chang, 2020). A number of studies have highlighted that various natural and genetically engineered microorganisms (GEM) such as Bacillus cereus, Chlorella pyrendoidosa, B. cereus XMCr-6, Pseudomonas veronii 2E, $P$. aeruginosa, Serratia marcescens, Sacharomyces cerevisiae, Penicillium canescens Spirogyra sp., Spirullina sp., and Cladophora sp. are responsible to remediate HMs such as $\mathrm{Cd}, \mathrm{Pb}, \mathrm{As}, \mathrm{Cr}, \mathrm{Mn}, \mathrm{Cu}, \mathrm{U}$, Se, and $\mathrm{Zn}$ from contaminated land and water (Lee and Chang, 2011; Kumar et al., 2011b; Hrynkiewicz et al., 2012; Kanmani et al., 2012; Mane and Bhosle, 2012; Mani and Kumar, 2014; Farhan and Khadom, 2015; Lívia et al., 2015; Ojuederie and Babalola, 2017; Verma and Kuila, 2019).

There is a need for characterization and regular assessment of various contaminated sites such as mining dumpsites, nuclear waste, surface wastewater, sewage sludge pump sites, agricultural soils, and various industrial and commercial dumping zones. Recently a number of research studies and literature reviews have been focused on the phytoremediation potential of particular plant species and selected metals with different microorganisms or particular microorganism-based remediation strategies (Raza et al., 2020; Yan et al., 2020; Wang et al., 2021; Hao et al., 2021; Sharma et al., 2021).

In this review, we have covered some new aspects and dimensions of bioremediation of heavy metal-polluted soils. Here, we have reviewed the recent literature published mainly between the year 2019-2021. There is a critical examination of the bioremediation potential of different microorganisms, especially bacteria and fungi individually and in association with plants. Further, the different mechanisms adopted by the microorganisms to detoxify HMs have also been discussed. Moreover, the study attempts to explore the knowledge about field applications with several case studies, factors affecting bioremediation, challenges, as well as future prospects have been covered.

\section{METHODOLOGY}

The relevant literature was searched and collected from the online database using Scopus, Web of Science, Google, Google Scholar, Springer Nature, Frontiers, Taylor and Francis, Science Direct, etc. The keywords used for the literature search 
include bioremediation, phytoremediation, phytoextraction, phytomanagement, remediation using living organisms, remediation through plant/microorganism, plant-microbe association for heavy metal removal, etc. In addition, particular focus journals such as International Journal of Phytoremediation, Bioremediation Journal, Frontiers in Microbiology, Journal of Environmental Management, Frontiers in Plant Science, Science of the Total Environment, Chemosphere, Water, Air, \& Soil Pollution, Environmental Science and Pollution Research, Microbial Research, etc. were browsed volume-wise for track the relevant papers until July 2021. The literature includes journal articles, books, book chapters, conference papers, proceedings, and technical reports were referred in this review paper from which $92.91 \%$ were published between the years 2010 to 2021 . In total, more than 400 documents were examined individually and eliminated the quotative and duplicate papers (Qi et al., 2018). Out of which 254 documents were selected for reference in this work.

\section{BIOREMEDIATION}

Bioremediation is an emerging and highly acceptable practice for restoring heavy metal contaminated soils, because of its environment friendly and low cost as compared to other conventional methods such as dredging, capping, and incineration that are often very costly and ineffective when metal concentration level is low and often generates a significant amount of toxic byproducts (Ekperusi and Aigbodion, 2015; Ayangbenro and Babalola, 2017). A study has been shown that it costs about 100-500 USD/ton for cleaning metalpolluted sediments and soils through landfilling and chemical treatment, and 90-870 USD/ton for vitrification, whereas about 15-200 USD/ton for bioremediation and 5-40 USD/ ton for phytoremediation (Meier et al., 2012). It estimates that bioremediation can save $50-65 \%$ for cleaning one acre of $\mathrm{Pb}$-contaminated soil compared to traditional excavation and landfill (Blaylock et al., 1997; Chibuike and Obiora, 2014). In addition, bioremediation is a non-invasive method that can remove contaminants permanently, leave the environment intact, and can be hybridized with chemical and physical treatments (Mani and Kumar, 2014). The bioremediation processes rely entirely on natural biological potency. The majority of bioremediation methods depends on several parameters such as soil structure, $\mathrm{pH}$ of the polluted sites, moisture content, type of the pollutants, nutrient supplement, microbial diversity, the temperature of treatment sites, and oxygen availability (Atagana et al., 2003; Thapa et al., 2012; Mangunwardoyo et al., 2013; Mani and Kumar, 2014). Bioremediation can occur naturally in a polluted site, which is called natural attenuation.

Lombi and Hamon (2005) have divided bioremediation into 'in-situ' and 'ex-situ' strategies. In-situ or on-site bioremediation is the most preferred option for removing contaminants from polluted soil and water. In the in-situ process, the soils remain confined to their initial location throughout the reclamation process, ending up in minimal site disturbance, fewer public health risks associated with excavation and off-site transport of contaminated soil, and reduced the overall cost over other remediation technologies (Hellekson, 1999; Lombi and Hamon, 2005). The in-situ bioremediation is broadly classified into two types, intrinsic and engineered bioremediation (Hazen, 2010). Intrinsic bioremediation takes place through the stimulations of indigenous microorganisms by supplying them with nutrients and oxygen to boost their metabolic activity. This is an unstimulated, unmanipulated, and unenhanced biological remedy of contaminates. Whereas for engineered bioremediation, a specific type of microorganisms or genetically engineered bacteria are introduced into the contaminated place to accelerates the degradation process by creating a conducive physicochemical condition (Kumar et al., 2011).

On the other side, ex-situ bioremediation methods require the excavation of polluted soil and water from its original location for the treatment. This is further categorized as a solid-phase system and slurry phase system. Solid-phase bioremediation includes contaminated waste such as industrial waste, domestic waste, municipal solid waste, and sewage sludge with organic waste including manure, leaves, and agricultural waste. The treatment process includes composting, soil biopile, hydroponics, and land farming, which create suitable conditions for indigenous anaerobic and aerobic microorganisms to boost the reclamation process (Kumar et al., 2011; Rayu et al., 2012). From which in hydroponics methods plants are grown in the mineral nutrient solution. Nowadays, this method is a common step for screening the suitable plant for phytoremediation by characterization of its response to heavy metal stress. On the other hand, slurry phase bioremediation is a speedy process where contaminated soils are mixed with additives and water in a bioreactor to create an appropriate environment for microorganisms to eliminate the contaminants.

\section{MECHANISMS OF BIOREMEDIATION}

Both in-situ and ex-situ remediation methods work on the principle of biotransformation/biodegradation, removal, mobilization, immobilization, or decontamination of various pollutants from the environment through the action of microorganisms (bacteria, fungi, and yeast) and plants (Abatenh et al., 2017). Microbes use chemical contaminants as an energy source during biotransformation and metabolize the target contaminant into useable energy via redox reactions. There are usually less harmful by-products or metabolites released back into the environment compared to the primary pollutants. For instance, microorganisms can degrade petroleum hydrocarbons through aerobic respiration in the presence of oxygen. The hydrocarbon gets oxidized by losing electrons, whereas the oxygen reduces by gaining electrons. Water and carbon dioxide are formed as a by-product of this redox reaction (Nester et al., 2001).

The microorganisms play an important role in HM remediation from the contaminated soil as they have acquired various mechanisms to tolerate the toxic effects of HMs. 
Microorganisms can sequester, precipitate, biosorb, and change the oxidation states of various metals (Ndeddy Aka and Babalola, 2016; Yin et al., 2019; Rizvi et al., 2020; Ibrahim et al., 2021). Metal sequestration happens by cell wall components and by intercellular metal bindings peptides and proteins such as metallothionein, phytochelatins with bacterial siderophores (Ojuederie and Babalola, 2017; Balzano et al., 2020). Microorganisms convert the toxic metal into a less toxic or innocuous form with the help of enzymes (such as dioxygenases, peroxidases, and oxidoreductases). The mechanisms applied by microorganisms to remove HMs from the contaminated soil or convert to less toxic form have been presented in Figure 1. However, the biosorption mechanism is based on two way: first depends on cell metabolism and second on the location of the cell where the HM is removed.

Three key bioremediation ingredients are (1) the presence of a contaminant, (2) the acceptor of electrons, and (3) the existence of microorganisms that can degrade a specific contaminant. Generally, the biodegradation process is easy for the naturally occurring contaminant or those have chemical similarities with naturally occurring compounds. It is due to the potential of microorganisms to destroy the contaminants. For instance, petroleum hydrocarbons are naturally derived chemical products, therefore microorganisms are habituated for these contaminants and can degrade them easily. Different approaches applied in the microbial remediation process such as bioattenuation, biostimulation, bioaugmentation for removing the toxic pollutants from the contaminated land, have been described below.

\section{Bioattenuation}

The contaminants are converted to less harmful or immobilized forms during bioattenuation. Such processes of immobilization and transformation are primarily attributed to microbial biodegradation and biological transformation (Smets and Pritchard, 2003), and, to some degree, to reactions with naturally occurring chemicals and geological media sorption. Contaminantspecific processes of natural attenuation are considered as methods for the remedy of fuel components [e.g., biosparging of benzene, toluene, ethylbenzene, and xylene (BTEX)], but not for other various classes of contaminants (e.g., sulfide and ferrous iron; Atteia and Guillot, 2007).

\section{Biostimulation}

This includes modification in environmental parameters, such as restricting nutrients supplement such as slow-release fertilizers, biosurfactants, and biopolymers (Kumar, 2019), which helps to remove the heavy metal, hydrocarbons and oil contaminants (Junior et al., 2019; Sun et al., 2019, 2021). It also enhances the bioavailability of $\mathrm{Cu}, \mathrm{Cd}, \mathrm{Pb}$, and $\mathrm{Zn}$, heavy metal uptake, translocation, and biodegradation rate of hydrocarbons, pesticides and herbicides by naturally existing microorganisms present on the site (Lim et al., 2016; Kumar, 2019). There are various fertilizers available as nutrients for microbes to stimulate, e.g.,

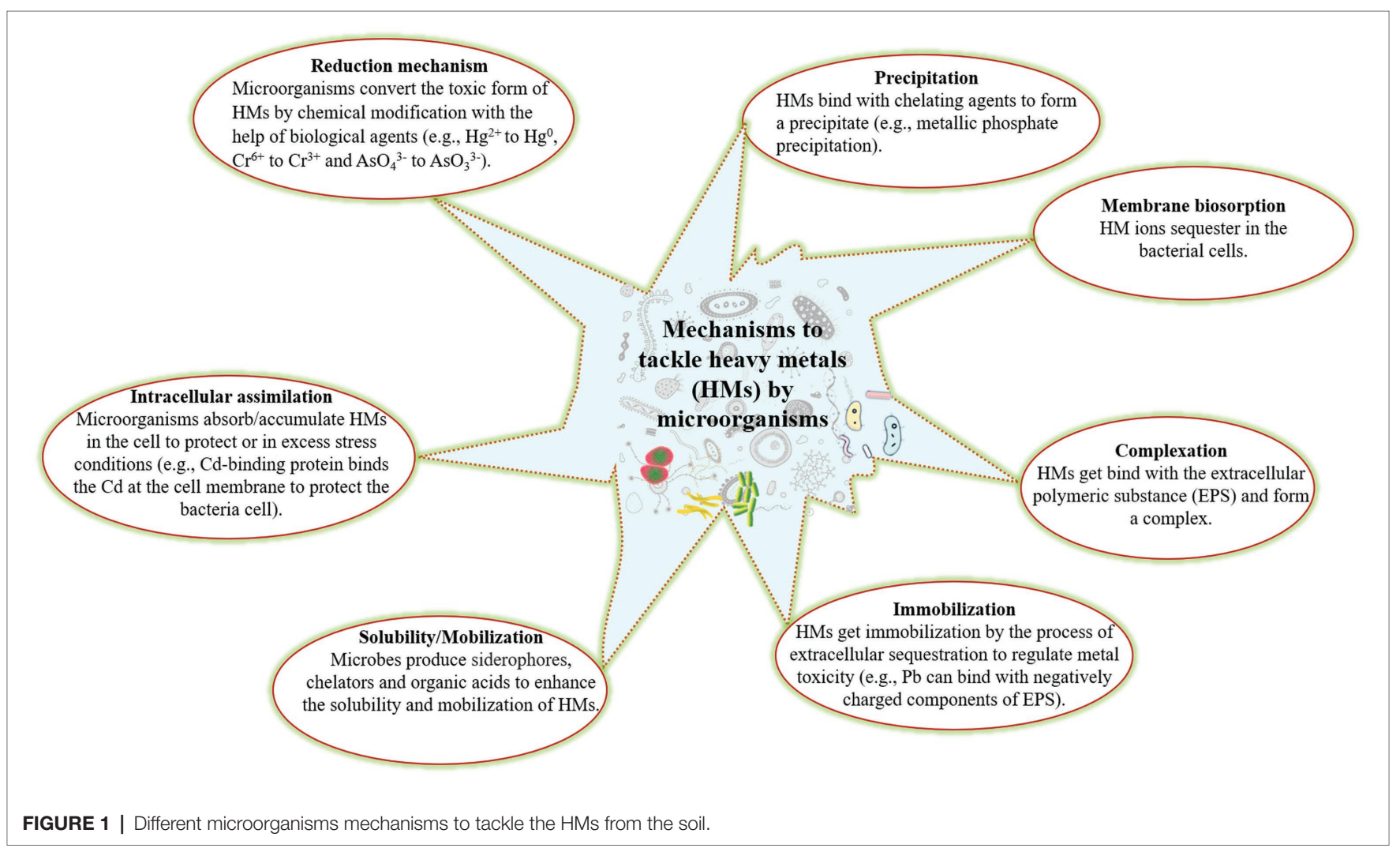


water-soluble $\mathrm{NaNO}_{3}, \mathrm{KNO}_{3}, \mathrm{NH}_{3} \mathrm{NO}_{3}$, slow-release customizable, max-bac, IBDU, and oleophilic Inipol EAP22, MM80, F1, S200.

\section{Bioaugmentation}

Bioaugmentation basically increases the heavy metal removal efficiency by introducing the pre-grown microorganisms. In this process, natural/exotic/engineered microbes are incorporated artificially in the heavy metal contaminated soil (Hassan et al., 2019, 2020a). Microbes are collected from the remediation site, separately cultured, genetically grown, and returned to the location. This process helps increase the growth and population of microorganisms, which enhance the solubility, mobility, accumulation of HMs, and increase the remediation efficacy (Atigh et al., 2020). However, it also reduces the risk of these pollutants either through chemically altering their chemical structure or by decreasing their bioavailability (Mandal et al., 2016; Hassan et al., 2019; Zanganeh et al., 2021). Recently this method is applied to various HM contaminated soil using different types of bacteria and fungal strains which include Oscillatoria sp., Leptolyngbya sp., Portulaca oleracea, Perenniporia subtephropora, Aspergillus niger MH541017, Daldinia starbaeckii, Tremates versicolor, and Tremates versicolor (Atigh et al., 2020; Hassan et al., 2020a; Zanganeh et al., 2021).

\section{PLANT-BASED BIOREMEDIATION}

Plants are used for bioremediation either alone or in combination with microbes (Ramos et al., 2005) instead of depending on microbes and their efficacy in achieving bioremediation of any contaminated medium. The application of green plants to clean up any contaminated medium or surface is not a novel concept. Plants were proposed for treating the wastewater around 300 years ago (Hartman, 1975). Presently a number of plant species such as Amaranthus spinosus, A. hypochondriacus Chrysopogon zizanioides, Brassica juncea, Ricinus communis, Chromolaena odorata, Ageratum conyzoides, Ipomoea carnea, Prosopis juliflora, Lantana camara, Parthenium hysterophorus, Fagopyrum esculentum, Odontarrhena chalcidica, Tagetes patula, T. erecta, and Odontarrhena chalcidica, have been identified which helpremediate HM contaminated soil (Bauddh and Singh, 2012; Bauddh and Singh, 2015; Huang et al., 2019; Chen et al., 2020a; Raza et al., 2020; Biswal et al., 2021; Cui et al., 2021; Gonzaga et al., 2021; Nugroho et al., 2021; Singh et al., 2021). In addition, plants like Nicotiana tabacum, Arabidopsis thaliana, Beta vulgaris and Sedum alfredii have been genetically modified with suitable bacterial genes from Caenorhabditis elegans, Saccharomyces cerevisiae, Streptococcus thermophilus, Pseudomonas fuorescens and employed for remediating the targeted contaminants (Daghan et al., 2013; Liu et al., 2015a; Wang et al., 2019; Nedjimi, 2021). For instance, mercury $(\mathrm{Hg})$ reductase bacterial genes, e.g., merA and merB have been applied in plants for the detoxification of methyl- $\mathrm{Hg}$ (Li et al., 2020a). In addition, various biostimulators, such as manure and organic amendments (e.g., various plant biochar, biosolids, and litter) are used in this plant-based bioremediation.
Use of different chelators such as citric acid, ethylene diamine tetraacetic acid (EDTA), [S,S]-ethylenediaminedisuccinic acid (EDDS), ethylenediamine-di-o-hydroxyphenylacetic acid (EDDHA), diethylenetriaminepentaacetic acid (DTPA), ethylene glycol tetraeacitic acid (AGTA), nhydroxyethylenediaminetriacetic acid (HEDTA), fulvic acids, salicyclic acid, and tartaric acid control metal sorption, and precipitation through the formation of metal chelate complexes, which consequently enhance the bioavailability of these metals and also improve phytoextraction efficiency (Caporale and Violante, 2016; Acuña et al., 2020; Saleem et al., 2020). The addition of chelates in soils can move more metals into soil solution via the suspension of precipitated compounds and desorption of sorbed species. Plants can also naturally produce various phytosiderophores, organic acids, and carboxylates, which can enhance metal mobility, solubility, and bioavailability in soils, thus increasing the phytoremediation potential of plants (Vithanage et al., 2012; Gupta and Singh, 2017). For instance, Miscanthus sinensis can detoxify Al by producing various phytosiderophores such as citric acid, malic acid, and chlorogenic acid and stored the metal in cell walls (Haruma et al., 2019).

Plant-based bioremediation is considered a potential tool for the accumulation, transformation, and immobilization of a low level of contaminants (Rayu et al., 2012). The mechanisms behind plants facilitate the reclamation of the polluted soils and groundwater are presented in Table $\mathbf{1}$. The approach of plant-based bioremediation has several merits such as cost-effectiveness, public acceptance, and the ability to remove inorganic and organic contaminants simultaneously. In a study, mixed mercury-trichloroethylene (Hg-TCE) pollutants are removed by transgenic alfalfa plants pKHCG co-expressing human P450 2E1 (CYP2E1) genes and glutathione S-transferase (GST; Zhang et al., 2013). A major synergistic effect caused by simultaneous expression of CYP2E1 and GST leads to increased accumulation and resistance of heavy metal-organic complex pollutants. Another study by Tammam et al. (2021) found that the plant Glebionis coronaria can eliminate $\mathrm{Pb}$ from the contaminated soil. It is also recorded that the foliar spray of Indole-3-acetic acid (IAA) and gibberellic acid (GA3) enhanced the growth significantly and increase the phytostabilization capacity of the studied plant. The application of bamboo biochar with the Salix psammophila to remediate the multi-metal contaminated soil, enhance the translocation factor (TF) and bioconcentration factors $(\mathrm{BCF})$ of $\mathrm{Cd}, \mathrm{Cu}$ and $\mathrm{Zn}$ ( $\mathrm{Li}$ et al., 2021a). The higher TF for $\mathrm{Zn}(\mathrm{TF}>1)$ and BCF for $\mathrm{Cd}(\mathrm{BCF}>1)$ makes S. psammophila a potential candidate for the phytoremediation in BBC amendment soil. Recently several studies found that the application of nanoparticles such as $\mathrm{Ag}$ nanoparticles (AgNPs), nano- $\mathrm{TiO}_{2}$ particles, nanoscale zero-valent iron (nZVI), salicylic acid nanoparticles (SANPs) and magnesium oxide $(\mathrm{MgO})$ nanoparticles along with plants Zea mays, Glycine max, Isatis cappadocica, Lolium perenne, Boehmeria nivea and Raphanus sativus enhance the growth and phytoextraction of $\mathrm{HMs} \mathrm{Cd}$ and $\mathrm{Pb}$ (Khan and Bano, 2016; Singh and Lee, 2016; Gong et al., 2017; Souri et al., 2017; Huang et al., 2018; Hussain et al., 2019). 
TABLE 1 | List of various phytoremediation mechanisms and plant species used in various process.

\begin{tabular}{|c|c|c|c|c|c|}
\hline Technique & Mechanism & Plant used & Plant parts & Surface medium & References \\
\hline Phytoextraction & $\begin{array}{l}\text { Uptake and accumulation of heavy } \\
\text { metal into plant tissues with } \\
\text { subsequent elimination of the } \\
\text { plants }\end{array}$ & $\begin{array}{l}\text { Brassica juncea } \\
\text { Amaranthus } \\
\text { hypochondriacus, } \\
\text { Thlaspi caerulescens }\end{array}$ & $\begin{array}{l}\text { Roots, Shoot, } \\
\text { Leaves }\end{array}$ & Soils & $\begin{array}{l}\text { Odoh et al., 2019; Cui } \\
\text { et al., 2021; Singh et al., } \\
2021\end{array}$ \\
\hline $\begin{array}{l}\text { Phytodegradation/ } \\
\text { Rhizodegradation }\end{array}$ & $\begin{array}{l}\text { Enzyme catalysed metabolism by } \\
\text { rhizosphere-dwelling } \\
\text { microorganisms to transform } \\
\text { organic contaminant into simpler } \\
\text { molecules }\end{array}$ & $\begin{array}{l}\text { Rhizophora mangle, } \\
\text { Salix viminalis, Vetiveria } \\
\text { zizanioides, Typha } \\
\text { latifolia }\end{array}$ & Roots, Leaves & Surface water, Groundwater & $\begin{array}{l}\text { Sampaio et al., 2019; } \\
\text { Papadopoulos and Zalidis, } \\
\text { 2019; Nedjimi, } 2021\end{array}$ \\
\hline Phytostabilization & $\begin{array}{l}\text { Decreases the mobility and } \\
\text { migration of soil contaminants }\end{array}$ & $\begin{array}{l}\text { Atriplex undulata, Salix } \\
\text { alba, Glebionis } \\
\text { coronaria }\end{array}$ & Roots & $\begin{array}{l}\text { Soils, Groundwater, Mine } \\
\text { tailing }\end{array}$ & $\begin{array}{l}\text { Mataruga et al., 2020; Li } \\
\text { et al., 2021; Tammam } \\
\text { et al., } 2021\end{array}$ \\
\hline Rhizofiltration & Uptake of metals via plant roots & $\begin{array}{l}\text { Eichhornia crassipes, } \\
\text { Lemna minor, Pistia } \\
\text { stratiotes }\end{array}$ & Roots & $\begin{array}{l}\text { Surface water, Water } \\
\text { pumped }\end{array}$ & $\begin{array}{l}\text { Kodituwakku and } \\
\text { Yatawara, 2020; Singh } \\
\text { et al., } 2021\end{array}$ \\
\hline Phytovolatilization & $\begin{array}{l}\text { Removal of pollutants such as } \\
\text { selenium, mercury, volatile } \\
\text { hydrocarbons via } \\
\text { evapotranspiration processes }\end{array}$ & $\begin{array}{l}\text { Arundo donax, Stanleya } \\
\text { pinnata, Brassica } \\
\text { juncea, B. Napus }\end{array}$ & Roots, Leaves & Soils, Groundwater & $\begin{array}{l}\text { Guarino et al., 2020; } \\
\text { Hasanuzzaman et al., } \\
\text { 2020; Yan et al., } 2021\end{array}$ \\
\hline Phytostimulation & $\begin{array}{l}\text { Phytostimulation (a symbiotic } \\
\text { relationship that exists between } \\
\text { plants and several soil } \\
\text { microorganisms) is developed for } \\
\text { the remediation of polychlorinated } \\
\text { biphenyl (PCBs) }\end{array}$ & $\begin{array}{l}\text { Brassica campestris, } \\
\text { Zea mays, glycine max }\end{array}$ & Roots & Soils & $\begin{array}{l}\text { Zahoor et al., 2017; Bilal } \\
\text { et al., } 2020\end{array}$ \\
\hline
\end{tabular}

Plants are effective in extracting inorganic and organic pollutants from the ground through the roots, they can also be transported and accumulated (phytoextraction/accumulation) in the harvestable parts of the plant (Pranaw et al., 2020). Transpiration to the atmosphere via leaf stomata (phytovolatilization) occurs in some instances (Rascio and Navari-Izzo, 2011). Phytodegradation of organic compounds are metabolized by plants in three sequential steps (namely transformation, conjugation, compartmentalization, respectively) with the aid of enzymes, e.g., cytochrome (CY) P450 and GT-glycosyltransferase (GT), which results in the storage of contaminant in the vacuole, incorporation into the cell wall, or excretion from the cell. In addition, plant-associated microorganisms in the rhizosphere (rhizodegradation) can degrade organic contaminants (Truu et al., 2015). By releasing root exudates and other compounds (e.g., organic acids) to the surrounding soil along with providing a surface for microbe colonization, plants can promote the biodegradation of pollutants, thereby contributing to the increased density and metabolic activity of microorganisms (rhizosphere effect) and contaminant bioavailability. Plant supplements nutrients to endophytic bacteria and stimulates catabolic gene expression. In turn, endophytic bacteria degrade organic contaminants, thereby reducing phytotoxicity and producing hormones (Shukla et al., 2020).

Since metal bioavailability in soils is relatively poor under most conditions, plants have very active metal uptake systems that utilize transporter molecules such as Zn-regulated transporter protein, Cu transporter protein, etc. (Krämer et al., 2007). In addition, plants are capable of acidifying the soil and mobilize soil-bound metals by secreting metal-chelating molecules to the surrounding soil, such as siderophores (catechol and hydroxymate), organic acids (e.g., citrate and malate), biosurfactants (rhamnolipids), protons from the root exudates (Yan et al., 2020; Bruno et al., 2021). Heavy metals cannot be biodegraded inside the plant, unlike organic contaminants, but can only be converted from one oxidation state/organic complex to another. It ends up in metal accumulation inside the plant. There are nearly 450 hyperaccumulator plants varies from annual to perennial herbs, shrubs, and trees (e.g., Brassica juncea, Zea mays, Ricinus communis, nicotiana tabacum, Helianthus annuus, Pteris vittata, Thlaspi caerulescens, Russian thistle, Sesbania drummondii, Salix matsudana, Populus deltoides), which have been identified to accumulate, metabolize and depollute extraordinary high concentration of metal ions (such as $\mathrm{Cd}, \mathrm{Pb}, \mathrm{Ni}, \mathrm{Co}, \mathrm{Mn}, \mathrm{Zn}$ ) in their above-ground tissues (Meagher, 2000; Padmavathiamma and Li, 2007; Shah and Nongkynrih, 2007; Sheoran et al., 2009; Palanivel et al., 2020).

\section{MICROORGANISM-BASED BIOREMEDIATION}

The capacity of microorganisms to degrade contaminants depends on their metabolic system through which the pollutants alter to innocuous form via the redox process (Jan et al., 2014). They help plants alleviate metal toxicity by sequestration of metals in cell wall components, alteration of the biochemical pathway to block metal uptake, reduction of the intercellular metal concentration via a precise efflux system, and conversion of poisonous metals to a less harmful state (Jan et al., 2014; 
Ojuederie and Babalola, 2017). Microorganisms (such as bacteria and fungi) play a vital role in the microbial bioremediation process. In addition, microorganisms contain several genes located in transposons and plasmids, which encode heavy metal resistant proteins and transporters. Recently, Kang et al. (2016) found that four bacterial strains, namely Enterobacter cloacae KJ-46, E. cloacae KJ-47, Sporosarcina soli B-22, and Viridibacillus arenosi B-21 had synergistic effects on the remediation of $\mathrm{Cd}$, $\mathrm{Pb}$, and $\mathrm{Cu}$ from contaminated soil. Moreover, the combination of bacteria strains shows greater resistance and efficacy for metal bioremediation compared to a single strain after $48 \mathrm{~h}$ of experiments. Microbes secrete several metabolites that play a significant role in bioremediation of contaminated sites (Sobrinho et al., 2013; Dixit et al., 2015; Coelho et al., 2015; Ahemad, 2019; Figure 2).

Bacteria generate siderophores that can diminish metal bioavailability and are subsequently eliminated from contaminated land (Ahemad, 2019). It is recorded that bacterial cell can alter their morphology to increase the production of siderophores for promoting the intercellular accumulation of metals (Manoj et al., 2020). Chibuike and Obiora (2014) found that a sulfatereducing bacterium Desulfovibrio desulfuricans can alter sulfate to hydrogen sulfate, which further reacts with $\mathrm{HMs}(\mathrm{Cd}$ and $\mathrm{Zn}$ ) and then form insoluble metal sulfides. The biomolecules of microbial cell walls contain negatively charged functional groups such as phosphate, hydroxyl, and carbonyl, which bind quickly with toxic metal ions and help them in bioremediation (Coelho et al., 2015; Dixit et al., 2015). Besides, bacteria can be grown and survive in any control and intense environmental conditions, making them a perfect bioremediation agent (Srivastava et al., 2015).

Likewise, fungi can be grown in harsh environmental conditions and detoxify metal ions by accumulation, valence transformation, and extra and intracellular precipitations (Ayangbenro and Babalola, 2017). In addition, fungi act as a promising biocatalyst in the bioremediation process, where they absorb toxic chemicals into their spores and mycelium. Recently, Hassan et al. (2020a) showed the bioremediation capability of fungal consortia of Ascomycota and Basidiomycota, suggesting fungal bioaugmentation helps decontaminate heavy metal from contaminated land. A number of investigations are carried to study the microorganism bioaccumulation and biosorption capacity for effectively remediate metal-contaminated environment (Table 2).

Recently researchers have been isolated various heavy metal resistance microorganism from contaminated lands, mining dumping and abandoned sites, industrial waste dumping yards, and the rhizosphere of plants growing in metal-contaminated sites (Banerjee et al., 2019; Aguilar et al., 2020; Akhter et al., 2020; Nurfitriani et al., 2020; Din et al., 2021; Sharma and Shukla, 2021b). The isolated bacterial genera (such as Arthrobacter, Enterobacter, Corynebacterium, Stenotrophomonas, Bacillus, and Pseudomonas) and fungi (such as Aspergillus flavus, Aspegillus awamori, Saccharomyces cerevisiae, Phanerochaete chrysosporium, Penicillium oxalicum, and Trichoderma viride) play a significant role in bioremediation process. Bacteria and fungi precisely used to eliminate the specific metals in recent years have been reviewed and presented in Tables 3, 4, respectively.

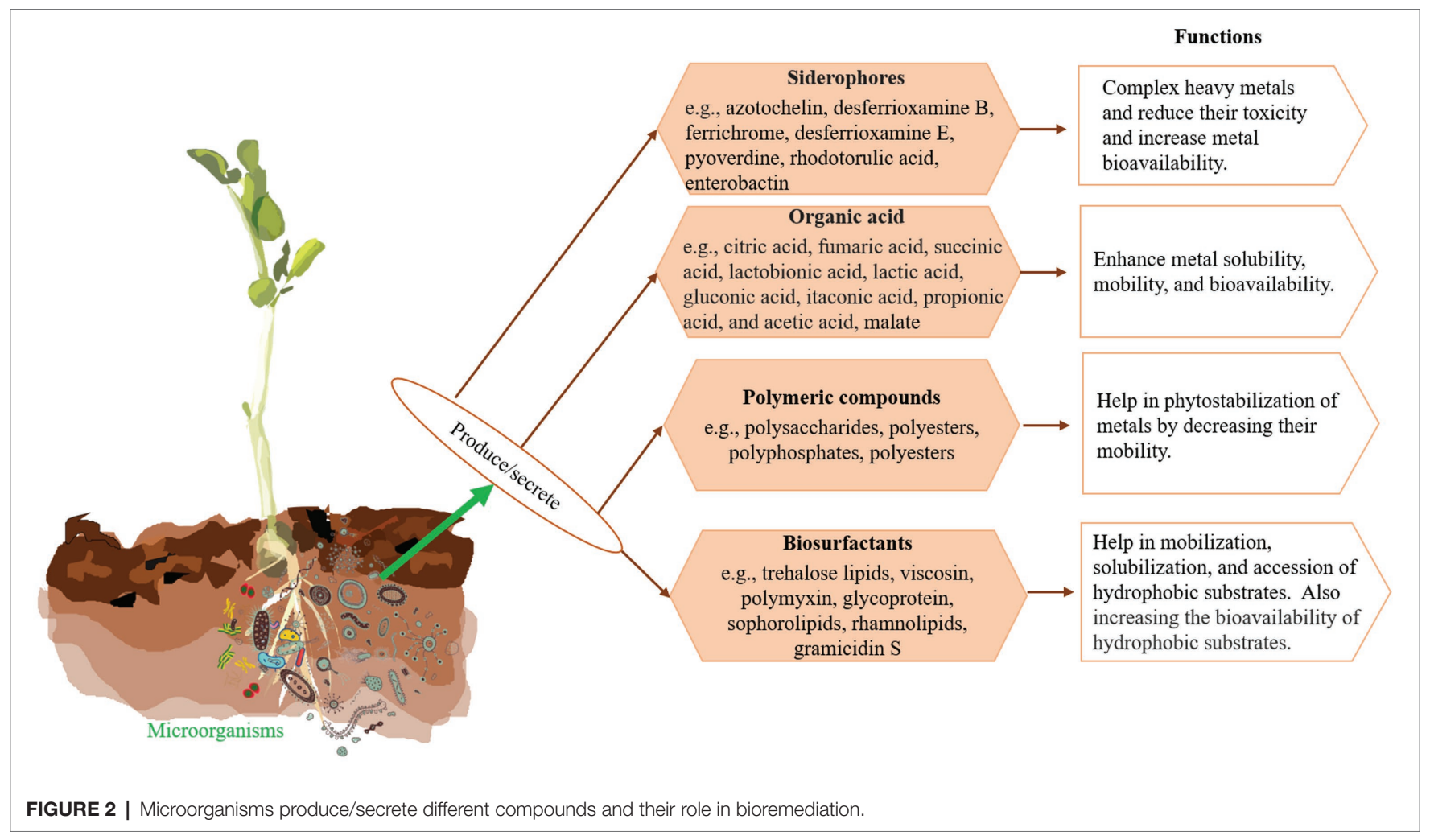


TABLE 2 | Different microorganisms and their bioaccumulation and biosorption capacity.

\begin{tabular}{|c|c|c|c|}
\hline Microorganism(s) & Contaminant(s) & Remarks & References \\
\hline $\begin{array}{l}\text { Scenedesmus acutus, Chlorella } \\
\text { pyrenoidosa }\end{array}$ & $\mathrm{Cd}$ & $\begin{array}{l}\text { C. pyrenoidosa and S. acutus accumulated } 3 \\
\text { and } 1.5 \% \text { of Cd and biosorbed } 97 \text { and } 98.5 \% \\
\text { of Cd, respectively. }\end{array}$ & Chandra et al., 2020 \\
\hline Aspergillus spp. & $\mathrm{Cd}, \mathrm{Cu}$ & $\begin{array}{l}\text { The removal efficiency for Cu and Cd was } \\
\text { recorded }>90 \% \text {. The biosorption potential of } \\
\text { living and dead cells for Cd was } 0.1977 \text { and } \\
0.1772 \mathrm{mg} \mathrm{g}^{-1} \text { and for Cu it was } 5.3676 \text { and } \\
18.661 \mathrm{mg} \mathrm{g}^{-1} \text {, respectively. }\end{array}$ & Hasgül et al., 2019 \\
\hline Streptomyces K11 & $\mathrm{Zn}$ & $\begin{array}{l}\text { The bioaccumulation capacity was } \\
4.4 \mathrm{mmol} \mathrm{g}^{-1} \text {. The maximum biosorption } \\
\text { capacity recorded was } 0.75 \mathrm{mmol}^{-1} \text {. }\end{array}$ & Sedlakova-Kadukova et al., 2019 \\
\hline Bacillus xiamenensis PbRPSD202 & $\mathrm{Pb}, \mathrm{Cd}, \mathrm{Cr}, \mathrm{As}, \mathrm{Ni}, \mathrm{Cu}$, and $\mathrm{Zn}$ & $\begin{array}{l}\text { The maximum } \mathrm{Pb} \text { biosorption capacity for } \\
\text { living and dead biomass of } B \text {. xiamenensis } \\
\text { shows } 216.75 \text { and } 207.4 \mathrm{mg} \mathrm{g}^{-1} \text {, respectively. }\end{array}$ & Mohapatra et al., 2019 \\
\hline Aspergillus flavus SFL & $\mathrm{Cr}$ & $\begin{array}{l}\text { The intercellular accumulation of } A \text {. flavus SFL } \\
\text { was } 50 \% \text { more than the reference strain. }\end{array}$ & Vajpai et al., 2020 \\
\hline Phanerochaete chrysosporium & $\mathrm{Cd}^{+2}, \mathrm{Ni}^{+2}$ & $\begin{array}{l}\text { The accumulation efficiency of } P \text {. } \\
\text { chrysosporium for } \mathrm{Cd}^{2+} \text { and } \mathrm{Ni}^{2+} \text { was } 96.23 \\
\text { and } 89.48 \% \text {. The maximum biosorption } \\
\text { capacity for } \mathrm{Cd}^{+2} \text { and } \mathrm{Ni}^{+2} \text { recorded } 71.43 \text { and } \\
46.50 \mathrm{mg} \mathrm{g}^{-1} \text {, respectively. }\end{array}$ & Noormohamadi et al., 2019 \\
\hline Pseudomonas azotoformans JAW1 & $\mathrm{Cd}, \mathrm{Pb}$, and $\mathrm{Cu}$ & $\begin{array}{l}\text { Metal accumulation occurs on the cell surface } \\
\text { (biosorption). The maximum adsorption found } \\
\text { of Cd, Pb, and Cu by } 98.57,88.57 \text { and } \\
69.76 \% \text {, respectively. The removal level } \\
\text { achieved the highest in order of Pb }(78.23 \%) \text {, } \\
\text { Cu }(63.32 \%) \text {, and Cd (44.67\%). }\end{array}$ & Choińska-Pulit et al., 2018 \\
\hline $\begin{array}{l}\text { Aspergillus tamari, Simplicillium } \\
\text { subtropicum, Aspergillus niger, } \\
\text { Fusarium solani, }\end{array}$ & $\mathrm{Cu}$ & $\begin{array}{l}\text { Although } A \text {. tamari and S. subtropicum growth } \\
\text { rate was low, the intake of Cu per unit of } \\
\text { biomass is high compare to two other species. }\end{array}$ & Ong et al., 2017 \\
\hline Ensifer adhaerens OS3 & $\mathrm{Cd}, \mathrm{Cr}, \mathrm{Ni}, \mathrm{Pb}, \mathrm{Cu}$, and $\mathrm{Zn}$ & $\begin{array}{l}\text { The maximum accumulation was recorded for } \\
\mathrm{Ni}(95 \%) \text { and lowest for } \mathrm{Pb}(74 \%) \text { and in order } \\
\text { of } \mathrm{Ni}>\mathrm{Cu}>\mathrm{Zn}>\mathrm{Cr}>\mathrm{Cd}>\mathrm{Pb} \text {. Biosorption } \\
\text { capacity recorded in order of } \\
\mathrm{Zn}>\mathrm{Cr}>\mathrm{Cd}>\mathrm{Ni}>\mathrm{Cu}>\mathrm{Pb} \text {. }\end{array}$ & Oves et al., 2017 \\
\hline
\end{tabular}

\section{PLANT-MICROBE ASSOCIATED REMEDIATION}

The microorganism-plant-based remediation has gain popularity currently due to its higher removal efficiency compared to plantbased remediation process. These microorganisms are involved in the various biochemical process such as carbon and nitrogen mineralization, nitrogen fixation, and decomposing organic matter, which contributes to soil formation, nutrient cycling and transfer of energy. Soil microorganisms are also affected by HMs in contaminated areas. However, with continuous exposer, they tend to tolerate and develop unique features with few specific microbial populations. These types of specific microbes can be employed for remediating toxic metals from contaminated lands. Further, soil microorganisms that form a symbiotic association with host plants are the most successful species in the soil reclamation process. The mycorrhizal fungi form intimate symbiotic relationship with host plants, which have been applied in many bioremediation processes (Yang et al., 2015; Gunathilakae et al., 2018; GonzálezChávez et al., 2019; Rubin and Görres, 2021). The arbuscular mycorrhizae as the most well-known symbiotic fungi are frequently used in phytoremediation due to their ubiquity in soil. They can develop several mechanisms to tolerate high metal concentrations in soils, thus promoting plant growth (Janoušková et al., 2005; Fasani et al., 2018). In addition, plant growthpromoting bacteria (PGPB) can also stimulate plant growth activities and help plants cope with the contaminated ecosystem. They can enhance plant growth through direct and indirect mechanisms that are discussed in the separated section below.

There are two aspects of plant-microbe-based bioremediation process. First of all is the microorganisms help the host plant sustain in the harsh environmental condition by providing nutrients. Second, the plant plays a critical role by maintaining favorable environmental conditions such as improving soil organic matter, available $\mathrm{P}, \mathrm{K}$, and $\mathrm{N}$, where soil microorganisms can thrive and enhance the reclamation process. Recently, a number of studies have been highlighted both side benefits of the plantmicrobe-based bioremediation process. A study recorded that planting of Trifolium repens in heavy metal contaminated sites improves soil enzymatic activities (Lin et al., 2021). Wang et al. (2021) also showed that plantation of Salix in Cd contaminated soil increased beneficial microorganisms diversity, such as genera of bacteria include Arthrobacter, Bacillus, Flavobacterium, Niastella, Novosphingobium, Niabella, Anaeromyxobacter, Rmlibacter, Solitalea, 
TABLE 3 | Metal bioremediation potential of bacteria strains.

\begin{tabular}{|c|c|c|c|}
\hline Targeted heavy metal & Bacteria used & Remarks & References \\
\hline $\mathrm{Cd}$ and $\mathrm{Pb}$ & $\begin{array}{l}\text { Enterobacter cloacae, Klebsiella } \\
\text { edwardsii and Pseudomonas } \\
\text { aeruginosa }\end{array}$ & $\begin{array}{l}P \text {. aeruginosa showed the highest bioremediation potential compared } \\
\text { to the other two with } 58.80 \text { and } 33.67 \% \text { of remediation in } 50 \mathrm{mg} \mathrm{Cd} \\
\mathrm{L}^{-1} \text { and } 300 \mathrm{mg} \mathrm{Pb} \mathrm{L}^{-1} \text {, respectively. }\end{array}$ & Oziegbe et al., 2021 \\
\hline $\mathrm{Pb}$ and $\mathrm{Ni}$ & $\begin{array}{l}\text { Ochrobactrum intermedium BPS- } \\
20 \text { and Ochrobactrum ciceri } \\
\text { BPS-26 }\end{array}$ & $\begin{array}{l}\text { O. intermedium BPS-20 and O. ciceri BPS-26 accumulated Pb by } \\
85.34 \text { and } 71.20 \% \text { and Ni by } 74.87 \text { and } 88.48 \% \text {, respectively. }\end{array}$ & Sharma and Shukla, 2021a \\
\hline $\mathrm{Pb}$ & Bacillus cereus BPS-9 & $\begin{array}{l}\text { BPS-9 strains recorded the highest } \mathrm{Pb} \text { accumulation potential of } \\
79.26 \% \text { and the biosorption capacity was } 193.93 \mathrm{mg} \mathrm{g}^{-1} \text {. }\end{array}$ & Sharma and Shukla, 2021b \\
\hline \multirow[t]{2}{*}{$\mathrm{Cr}, \mathrm{Pb}$, and $\mathrm{Ni}$} & \multirow{2}{*}{$\begin{array}{l}\text { Klebsiella pneumoniae MB361, } \\
\text { Stenotrophomonas sp. MB339, } \\
\text { and Staphylococcus sp. MB371 }\end{array}$} & $\begin{array}{l}\text { The percentage of accumulation increase gradually with time and } \\
\text { increased biomass. }\end{array}$ & \multirow[t]{2}{*}{ Aslam et al., 2020} \\
\hline & & $\begin{array}{l}\text { The highest removal was recorded by } \mathrm{MB} 339 \text { with } \mathrm{Pb}(85.30 \%) \text {, and } \\
\mathrm{Ni}(48.78 \%) \text {, followed by } \mathrm{MB} 361 \text { with } \mathrm{Cr}(83.51 \%) \text {, while MB371 } \\
\text { sorbed } \mathrm{Pb} \text { by } 88.33 \% \text {. }\end{array}$ & \\
\hline $\mathrm{Ni}$ & $\begin{array}{l}\text { Pseudomonas sp. P21, } \\
\text { Stenotrophomonas sp. S20, and } \\
\text { Sphingobium sp. S42 }\end{array}$ & $\begin{array}{l}\text { Bacterial strains } \mathrm{S} 20 \text { and P21 show high tolerant levels to Ni up to } \\
400 \mathrm{mg} \mathrm{L}^{-1} \text {, while S42 removed } 33.7 \% \text { of metal. }\end{array}$ & Chen et al., 2020 \\
\hline $\mathrm{Hg}$ & $\begin{array}{l}\text { Fictibacillus nanhainensis SKT-B } \\
\text { and Bacillus toyonensis PJM-F1 }\end{array}$ & $\begin{array}{l}\text { F. nanhainensis SKT-B accumulated the highest level of Hg followed } \\
\text { by B. toyonensis PJM-F1 with } 82.25 \text { and } 81.21 \% \text {, respectively. }\end{array}$ & Nurfitriani et al., 2020 \\
\hline $\mathrm{Co}$ and $\mathrm{Ni}$ & Anoxybacillus mongoliensis & $\begin{array}{l}\text { The highest accumulation by bacteria recorded for } \mathrm{Co} \text { and Ni was } \\
274.9 \text { and } 268.5 \mathrm{mg} \mathrm{g}^{-1} \text {, respectively. Further, increasing activities of } \\
\text { superoxide dismutase (SOD) and catalase (CAT) were also } \\
\text { recorded. }\end{array}$ & Akkoyun et al., 2020a \\
\hline $\mathrm{Pb}, \mathrm{Cd}$, and $\mathrm{Ni}$ & $\begin{array}{l}\text { Rhizopus stolonifer and Bacillus } \\
\text { megaterium }\end{array}$ & $\begin{array}{l}\text { When growing the bacteria separately, } R \text {. stolonifer and } B \text {. } \\
\text { megaterium recorded maximum uptake of } \mathrm{Cd} \text { and } \mathrm{Ni} \text { by } 479.10 \text { and } \\
501.05 \mathrm{mg} \mathrm{L}^{-1} \text {, respectively. Overall } B \text {. megaterium uptake a higher } \\
\text { concentration of combined HMs. }\end{array}$ & Njoku et al., 2020 \\
\hline $\mathrm{Cr}$ & $\begin{array}{l}\text { Bacillus cereus AVP12 and } \\
\text { Bacillus cereus NC7401 }\end{array}$ & $\begin{array}{l}\text { The highest Cr accumulation potential of AVP12 and NC7401 strains } \\
\text { isolated from the contaminated sites was } 181.0 \text { and } 107.5 \mathrm{mg} \mathrm{L}^{-1} \text {, } \\
\text { respectively. While for the same strains AVP12 and NC7401 isolated } \\
\text { from non-polluted sites were } 92.59 \text { and } 62.11 \mathrm{mgL}^{-1} \text {, respectively. }\end{array}$ & Akhter et al., 2020 \\
\hline $\mathrm{Hg}$ and $\mathrm{Pb}$ & Exiguobacterium profundum & $\begin{array}{l}\text { The highest bioaccumulation of } \mathrm{Pb} \text { and } \mathrm{Hg} \text { for } \mathrm{E} \text {. profundum were } \\
54.35 \text { and } 37.56 \mathrm{mg} \mathrm{g}^{-1} \text {, respectively. }\end{array}$ & Akkoyun et al., 2020b \\
\hline $\mathrm{Cr}, \mathrm{Ni}$, and $\mathrm{Pb}$ & $\begin{array}{l}\text { Lactobacillus plantarum } \\
\text { MF042018 }\end{array}$ & $\begin{array}{l}\text { It shows high tolerance against the } \mathrm{Ni} \text { and } \mathrm{Cr} \text { up to } 500 \text { and } 100 \mathrm{ppm} \text {, } \\
\text { respectively. The biosorption capacity of MF0 } 42018 \text { was recorded } \\
\text { very high for } \mathrm{Cd} \text { and } \mathrm{Pb} \text { at } \mathrm{pH} 2.0 \text { and temperature } 22^{\circ} \mathrm{C} \text { after } 1 \mathrm{~h} \text {. }\end{array}$ & Ameen et al., 2020 \\
\hline As & $\begin{array}{l}\text { Bacillus cereus and Lysinibacillus } \\
\text { boronitolerans }\end{array}$ & $\begin{array}{l}\text { The bacterial strains P2IIB, P1C1llb and P2lc resistant to } 3,000 \mathrm{mg} \mathrm{L}^{-1} \\
\text { of As. The bacteria culture removes } 85.72 \% \text { of arsenate and } 71.88 \% \\
\text { of arsenite from the medium. }\end{array}$ & Aguilar et al., 2020 \\
\hline $\mathrm{Cr}$ & Bacillus cereus & $\begin{array}{l}\text { The bacteria strain can tolerate } \mathrm{Cr}_{2000}\left(2,000 \mathrm{mg} \mathrm{L}^{-1}\right) \mathrm{Cr}(\mathrm{VI}) \text { and can } \\
\text { completely decrease } \mathrm{Cr}_{200} \text { under heterotrophic conditions within } 16 \mathrm{~h} \text {. } \\
\text { It is recorded that } \mathrm{Cr}(\mathrm{VI}) \text { was effectively reduced to } \mathrm{Cr}(\mathrm{III}) \text {. }\end{array}$ & Banerjee et al., 2019 \\
\hline As & $\begin{array}{l}\text { Ochrobactrum ciceri SW1 and } \\
\text { Exiguobacterium profundum PT2 }\end{array}$ & $\begin{array}{l}\text { Both bacterial strains increased production of EPS in the presence of } \\
\text { As, which help to sequester arsenic. }\end{array}$ & Saba et al., 2019 \\
\hline $\mathrm{Hg}, \mathrm{Cd}, \mathrm{Pb}, \mathrm{Cu}, \mathrm{Ni}$, and $\mathrm{Zn}$ & Escherichia coli K-12 & $\begin{array}{l}\text { The bacterial strain can absorb different types of metal ions. It can } \\
\text { absorb more than } 30 \text { varieties of metal ions via its outer membrane. }\end{array}$ & Jin et al., 2018 \\
\hline $\mathrm{Cd}$ & $\begin{array}{l}\text { Cupriavidus necator GX_5, } \\
\text { Sphingomonas sp. GX_15, and } \\
\text { Curtobacterium sp. GX_31 }\end{array}$ & $\begin{array}{l}\text { The highest removal capacity of Cd recorded in order of GX_31, } \\
\text { GX_15 and GX_5 with } 86.06,53.88 \text { and } 25.05 \% \text {, respectively. }\end{array}$ & Li et al., 2018 \\
\hline
\end{tabular}

Devosia, Mesorhizobium Nitrospira, Thermomonas, Flavisolibacter, Pedomicrobium, Lysobacter, Rubrivivax Phyllobacterium, and mycorrhizal genera of fungi include Actinomucor, Conocytes, Amanita, Cryptococcus, Xylaria, Ramicandelaber, Spizellomyces, Sporobolomyces, Rhodotorula Umbilicaria, Claroideoglomus, Tilletiopsis, and Cirrenalia in plant rhizosphere.

\section{Plant Growth-Promoting Bacteria}

It is well known that PGPB can enhance phytoremediation efficiency (Ma et al., 2016; Lin et al., 2021; Kumar et al., 2021a). The PGPB may directly prompt root proliferation and improve plant growth and fitness, plant metal resistance, uptake and translocation of nutrients and metals, and protect plants from phytopathogens (Ma et al., 2011; Gupta et al., 2013; Fasani et al., 2018) by producing and secreting various organic acids, polymeric compounds, chelators, and hormones such as indole-3-acetic acid (IAA), 1-aminocyclopropane-1carboxylate (ACC) deaminase, polysaccharides, glomalinand, azotobactin, azotochelin, alcaligin E, pyochelin, coelichelin, ferrioxamine $\mathrm{B}$, and pyoverdin, which are responsible for decrease the soil $\mathrm{pH}$ and enhance the metal bioavailability, whereas the polymeric compounds help in phytostabilization 
of metals by decreasing their mobility (Chen et al., 2017). The chelators work as metal-binding ligands to enhance metal bioavailability, improve root-shoot translocation and metal uptake capacity, and facilitate intracellular heavy metal accumulation in organelles (Yan et al., 2020). Inoculation of ACC deaminase-producing PGPB showed extensive root and shoot density along with increased biomass and phytoremediation efficiencies (Arshad et al., 2007; Yan et al., 2020). It is found that Bacillus sp. XZM lowers As toxicity to the plant by producing a higher amount of extracellular polymeric substance (EPS), siderophore, and IAA (Irshad et al., 2020). Some of PGPB, such as Pseudomonas, Micrococcus, Erwinia, Azospirillium, Flavobacterium, Azotobacter, Chromobacterium, and Agrobacterium have been applied in the phytoremediation process (Bhattacharyya and Jha, 2012; Ma et al., 2019). Ma et al. (2016) isolated two droughts resistant serpentine PGPB Pseudomonas reactans $\mathrm{Ph} 3 \mathrm{R} 3$ and Pseudomonas libanensis that showed high resistance to different HMs ( $\mathrm{Cd}, \mathrm{Cr}, \mathrm{Pb}, \mathrm{Cu}, \mathrm{Ni}$, and $\mathrm{Zn})$, salinity, extreme temperature, and antibiotics. Both strains significantly enhanced plant growth, pigment content, and leaf relative water, and also translocation and bioconcentration factors for $\mathrm{Cu}$ and $\mathrm{Zn}$ under the drought condition.

Further, PGPB are found to be an important player in remediating the $\mathrm{HM}$ contaminated marine ecosystems. The study by Mesa-Marín et al. (2020) recorded that inoculation of Thalassospira australica SRT8, Vibrio neocaledonicus SRT1 and Pseudarthrobacter oxydans SRT15, with Salicornia ramosissima improved the relative plant growth rate and the number of new branches by 32 and $61 \%$, respectively, when planted in the HM contaminated estuarine soil. The inoculation of PGPB also helps to accumulate the highest concentration of $\mathrm{HMs}$ like $\mathrm{As}, \mathrm{Cd}, \mathrm{Cu}, \mathrm{Ni}, \mathrm{Pb}$ and $\mathrm{Zn}$ in the root and subsequently enhance the phytoremediation potential of $S$. ramosissima. In one another study inoculation of Bacillus flexus KLBMP 4941 with coastal halophytes Limonium sinense under the salt stress ecosystem shows positive effects on the hostplant survival and growth and it can be employed for phytoremediation of saline soils (Xiong et al., 2020). Two PGPB namely Bacillus cereus strain P2 and Planomicrobium chinense strain P1 isolated by Khan et al. (2018) and inoculated with Helianthus annus for phytoremediation of HMs in drought conditions found a significantly positive result. The study confirmed that the application of PGPB and salicylic acid significantly increased the rhizosphere accumulation of $\mathrm{Cd}, \mathrm{Pb}, \mathrm{Ni}$ by 84,66 and $65 \%$, respectively. In addition, inoculation of PGPB significantly enhanced the root length, shoot length, root fresh, and dry weight by $68,60,61$, and $63 \%$, respectively. Likewise, in various studies different types of PGPB such as Bacillus subtilis, Bacillus thuringiensis, Ensifer meliloti RhOL6 and RhOL8, Bacillus megaterium, Pseudomonas sp. DSP17 and Proteus sp. DSP1 have been applied along with organic and inorganic amendments found enhanced remediation of HMs from different types of soils which include sandy soil, arid and semi-arid soils (Khan and Bano, 2018; Raklami et al., 2019; Khodaverdiloo et al., 2020).
Generally, associations of leguminous plants with PGPB have also been applied in the phytoremediation process of highly metal-contaminated sites (Hao et al., 2014). But recently, this remediation method is used in less or moderately metalcontaminated agriculture soil (Saadani et al., 2019). Recently, Saadani et al. (2019) found that the inoculation of PGPB with Sulla coronaria and Vicia faba L. var. minor showed a higher metal accumulation in legumes grown in low contaminated agriculture soil compared to non-inoculated legumes. After the cultivation of symbiotic legumes, soil fertility is positively affected with higher organic content (phosphorous and nitrogen) and soil decomposition rate. The rhizobium-legume symbiosis relationship between high metal-resistant Sinorhizobium meliloti CCNWSX0020 and plant Medicago lupulina has been successfully used in the study for efficient bioremediation of HMs (Lu et al., 2017). It is also recorded that the bacterial strain's extracellular polymeric substances help to immobilize $\mathrm{Cu}^{2+}$. The genetically engineered rhizobium-legume symbiont is also used to remediate the As contamination from the soil. A study by Zhang et al. (2017) inserted the arsenite [As (III)] S-adenosylmethionine methyltransferase gene (CrarsM) derived from alga Chlamydomonas reinhardtii in Rhizobium leguminosarum bv. trifolii strain R3 and check the As methylation capacity by symbiosis with red clover found a positive result in the test. Likewise, Tsyganov et al. (2020), applied two transgenic strains of Rhizobium leguminosarum bv. viciae, 3,841-PsMT2 and 3,841PsMT1 to pea plants (Pisum sativum) for the study of $\mathrm{Cd}$ tolerance and accumulation in plants. The study concludes that the pair of legume-rhizobia may be applied for phytostabilization purposes.

\section{Arbuscular Mycorrhizal Fungi}

AMF are mostly found in terrestrial plant roots by forming the symbiotic association. In the root cortex, the fungus colonizes and develops a thick extended mycelium around the roots, which acts as an intermediatory connection between plants and soils and helps absorb nutrients from soils (Kernaghan, 2005; Reinhardt, 2007). AMF are also found in highly disturbed ecosystems or polluted soils (Cornejo et al., 2008; Yan et al., 2020). AMF can confer plant metal resistance (Singh, 2012; Xu et al., 2012; Curaqueo et al., 2014; Gunathilakae et al., 2018). AMF is a tremendous biological interest due to its positive effects on symbiotic relationships and remediation capability. Further, it has been exploring in every way to employ AMF for stabilizing the metals in contaminated land. The mycorrhizal plants enhance metal phytostabilization by metal sequestration in roots and hyphae. The metals confined to soils make them less bioavailable. Thus, the toxic effects of metals on other living microorganisms are alleviated.

Many studies have been conducted to investigate the role of AMF in phytoremediation (Table 5). Liu et al. (2015b) conducted a study on Cd uptake capacity of Solanum nigrum inoculated with Glomus versiforme BGC GD01C (Gv) in different $\mathrm{Cd}$ concentrations soil. They found that the inoculation of $G$. versiforme highly improved the total Cd uptake in plants at different $\mathrm{Cd}$ concentrations. Many researchers have attempted 
TABLE 4 | Metal bioremediation potential of fungi strains.

\begin{tabular}{|c|c|c|c|}
\hline Target heavy metal & Fungi used & Remarks & References \\
\hline $\mathrm{Cd}$ & $\begin{array}{l}\text { Penicillium chrysogenum } \\
\text { FMS2 }\end{array}$ & $\begin{array}{l}\text { The highest tolerance level recorded for } P \text {. chrysogenum FMS2 was } \\
1,000 \mathrm{mg} \mathrm{L}^{-1} \text {. The fungal strain can survive in the wide environmental } \\
\text { condition such as temperature and } \mathrm{pH} \text { range between } 15-35^{\circ} \mathrm{C} \text { and } 4.0- \\
12.0 \text {, respectively. The Cd removal capacity of fungi was approximately } \\
49 \% \text { in } 15 \text { days of exposure. }\end{array}$ & Din et al., 2021 \\
\hline $\mathrm{Cd}, \mathrm{Cu}, \mathrm{Ni}, \mathrm{Pb}$, and $\mathrm{Zn}$ & Ganoderma lucidum & $\begin{array}{l}\text { The concentration of } \mathrm{Pb}, \mathrm{Zn}, \mathrm{Ni}, \mathrm{Cu} \text { and } \mathrm{Cd} \text { in contaminated soil were } \\
4,490,147,27.7,19.4 \text { and } 2.18 \mathrm{mg} \mathrm{kg}^{-1} \text { and } \mathrm{G} \text {. lucidum accumulated } 138 \text {, } \\
29.8,3.48,3.69 \text { and } 1.01 \mathrm{mg} \mathrm{kg}^{-1} \text { of respective metal after inoculated in } \\
\text { contaminated soil. }\end{array}$ & Ipeaiyeda et al., 2020 \\
\hline $\mathrm{Pb}$ & $\begin{array}{l}\text { Aspergillus niger, Penicillium } \\
\text { oxalicum, and Trichoderma } \\
\text { asperellum }\end{array}$ & $\begin{array}{l}\text { Trichoderma, Penicillium and Aspergillus accumulate Pb ions by } 75.29 \text {, } \\
66.77 \text {, and } 56.82 \% \text {, respectively. }\end{array}$ & Mariconi et al., 2020 \\
\hline $\mathrm{Pb}, \mathrm{Ni}$, and $\mathrm{Zn}$ & $\begin{array}{l}\text { All isolated fungi, Ascomycota } \\
\text { and Basidiomycota }\end{array}$ & $\begin{array}{l}\text { The highest bioremoval capacity for } \mathrm{Ni} \text { and } \mathrm{Pb} \text { was } 52 \text { and } 44 \% \text { from the } \\
\text { bioaugmented soil with all isolated fungi. While for } \mathrm{Zn} \text {, the maximum } \\
\text { removal was } 36 \% \text { in } \mathrm{A} \text {. consortium-treated soil. Overall, } \mathrm{Pb} \text { and Ni removal } \\
\text { efficacy in order of isolated fungi > Basidiomycota }>\text { Ascomycota, whereas } \\
\text { for } \mathrm{Zn} \text { it was Basidiomycota }>\text { all isolated fungi }>\text { Ascomycota. }\end{array}$ & Hassan et al., 2020a \\
\hline As, Cr, Cu, Mn, and Fe & $\begin{array}{l}\text { All isolated fungi, Ascomycota } \\
\text { and Basidiomycota }\end{array}$ & $\begin{array}{l}\text { Fungal consortia show the highest tolerance index of } 1.0 \text { for } \mathrm{Cr} \text {, Cu and Fe } \\
\text { in agar medium. Further, the consortium of all isolated fungi shows the } \\
\text { removal capacity of As, } \mathrm{Mn}, \mathrm{Cr} \text {, and } \mathrm{Cu} \text { by } 77,71,60 \text { and } 52 \% \text {, respectively. }\end{array}$ & Hassan et al., 2020b \\
\hline As & $\begin{array}{l}21 \text { fungal strains including } \\
\text { Humicola sp. }\end{array}$ & $\begin{array}{l}\text { All the isolated fungal strains can tolerate up to } 5,000 \mathrm{mg} \mathrm{L}^{-1} \mathrm{AsV} \text {. The } \\
\text { accumulation capacity of fungi biomass ranged between } 0.146 \text { to } \\
11.36 \mathrm{~g} \mathrm{~kg}^{-1} \text { and volatilization of As between } 0.05 \text { to } 53.39 \mathrm{mg} \mathrm{kg}^{-1} \\
\text { biomass. Humicola sp. recorded the highest biovolatilization capacity by } \\
53.39 \mathrm{mg} \mathrm{kg}^{-1} \text {. }\end{array}$ & Tripathi et al., 2020 \\
\hline $\mathrm{Hg}$ & Penicillium spp. DC-F11 & $\begin{array}{l}\text { DC-F11 fungal strain detoxified Hg via extracellular sequestration through } \\
\text { precipitation and adsorption. }\end{array}$ & Chang et al., 2020 \\
\hline $\mathrm{Hg}$ & $\begin{array}{l}\text { Aspergillus sp. A31, } \\
\text { Lindgomycetaceae P87, } \\
\text { Curvularia geniculata P1, and } \\
\text { Westerdykella sp. P71 }\end{array}$ & $\begin{array}{l}\text { All four species of endophytic fungi remove up to } 100 \% \text { of } \mathrm{Hg} \text { in a species- } \\
\text { dependent manner from the culture medium. }\end{array}$ & Pietro-Souza et al., 2020 \\
\hline $\mathrm{Cd}$ & Aspergillus fumigatus & $\begin{array}{l}\text { A. fumigatus showed the highest tolerance against Cd with a removal } \\
\text { percentage of } 74.76 \text { and uptake capacity of approximately } 5.02 \mathrm{mg} \mathrm{gm}^{-1} \text {. }\end{array}$ & Talukdar et al., 2020 \\
\hline $\mathrm{Cd}$ and $\mathrm{Pb}$ & Simplicillium chinense QD10 & $\begin{array}{l}\text { Cd biosorption occurs with forming } \mathrm{Cd} \text {-chelate and } \mathrm{Pb} \text { mainly adsorbed by } \\
\text { extracellular polymeric substances (EPA). }\end{array}$ & Jin et al., 2019 \\
\hline $\mathrm{Cu}, \mathrm{Cd}, \mathrm{Pb}$, and $\mathrm{Zn}$ & $\begin{array}{l}\text { Alternaria } \\
\text { chlamydosporigena, } \\
\text { Trichoderma harzianum, } \\
\text { Acremonium persicinum, } \\
\text { Fusarium verticillioides, } \\
\text { Seimatosporium pistaciae, } \\
\text { and Penicillium } \\
\text { simplicissimum }\end{array}$ & $\begin{array}{l}\text { T. harzianum was found the maximum tolerant against } \mathrm{Cd}, \mathrm{Cu} \text { and } \mathrm{Pb} . \mathrm{A} \text {. } \\
\text { persicinum and } P \text {. simplicissimum record the highest biosorption and } \\
\text { accumulation of HMs. }\end{array}$ & Mohammadian et al., 2017 \\
\hline $\mathrm{Cd}, \mathrm{Cr}, \mathrm{Cu}, \mathrm{Ni}$, and Zn & Beauveria bassiana & $\begin{array}{l}\text { It removed } 84 \% \text { multi-metal from the mixture sample while individual metal } \\
\text { removal capacity was } 61-75 \% \text {. B. bassiana removed the metal via } \\
\text { accumulation and sorption processes. }\end{array}$ & Gola et al., 2016 \\
\hline $\mathrm{Cu}, \mathrm{Pb}$ & Aspergillus flavus and A. niger & $\begin{array}{l}\text { The biosorption of } \mathrm{Cu} \text { and } \mathrm{Pb} \text { by } A \text {. flavus and } A \text {. niger was recorded } 81.8 \\
\text { and } 83.1 \% \text {, respectively, during the initial } 10 \mathrm{~min} \text {. }\end{array}$ & Iram et al., 2015 \\
\hline
\end{tabular}

to explore more possibilities to remediate the contaminants from the stressed environment. Recently, a study conducted by Hao et al. (2021) showed that the phytoremediation potential of Zea mays inoculated with Claroideoglomus etunicatum grown in Lanthanum (La) contaminated soils enhanced bacterial diversity including Agrococcus, Lysobacter, Planomicrobium, Microbacterium, Streptomyces, Saccharothrix, Penicillium, and other unclassified bacteria and fungi like Penicillium. This study confirmed that AMF can regulate the rhizosphere fungal and bacterial diversity to foster beneficial microorganisms that help the plant sustain. Further, an investigation is undertaken in $\mathrm{Ni}$ contaminated saline soil for remediation using Helianthus annuus inoculated with plant beneficial bacteria (Pseudomonas libanensis TR1) and AMF (Claroideoglomus claroideum BEG210; Ma et al., 2019). The study found that the bacteria and fungi alone or in combination, significantly increase plant growth, physiological parameters, and accumulation of $\mathrm{Ni}$ and $\mathrm{Na}^{+}$, thus contributing significantly to $\mathrm{Ni}$ Phytostabilization, $\mathrm{Na}^{+}$and $\mathrm{Ni}$ detoxification, and $\mathrm{Na}^{+}$ exclusion. Therefore, bioaugmentation with PGPB with AMF can be used as a useful strategy for reclaiming metalcontaminated saline soil. 
TABLE 5 | Role of microorganisms in the removal of heavy metals by plants.

\begin{tabular}{|c|c|c|c|c|}
\hline Targeted heavy metal & Microorganisms used & Host plant & Remarks & References \\
\hline \multicolumn{5}{|l|}{ Bacteria } \\
\hline $\mathrm{Cd}, \mathrm{Cu}, \mathrm{Ni}, \mathrm{Pb}$, and $\mathrm{Zn}$ & Bacillus cereus TCU11 & Zea mays & $\begin{array}{l}\text { TCU11 significantly enhanced the biomass, } \\
\text { chlorophyll, carotenoids, proline, phenolics, protein } \\
\text { and antioxidant enzymes. It also increased the } \\
\text { translocation of metals except for Ni. Overall, it } \\
\text { improves the phytoremediation efficiency. }\end{array}$ & Bruno et al., 2021 \\
\hline $\mathrm{Cu}$ & $\begin{array}{l}\text { Pseudomonas lurida } \\
\text { EOO26 }\end{array}$ & Helianthus annuus & $\begin{array}{l}\text { Inoculation of EOO26 increased the } \mathrm{Cu} \\
\text { accumulation in roots and leaves by } 8.6 \text { and 1.9- } \\
\text { fold, respectively, and total plant uptake by } 2.6- \\
\text { fold compared to the uninoculated plants. }\end{array}$ & Kumar et al., 2021a \\
\hline $\mathrm{Cd}, \mathrm{Pb}$, and $\mathrm{Cr}$ & $\begin{array}{l}\text { Adhaeribacter, } \\
\text { Kaistobacter, Lysobacter, } \\
\text { Pontibacter, } \\
\text { Flavisolibacter, Bacillus }\end{array}$ & Trifolium repens & $\begin{array}{l}\text { Kaistobacter, Lysobacter and Pontibacter } \\
\text { significantly helped in metal accumulation, } \\
\text { whereas the other three species enhanced plant } \\
\text { growth. }\end{array}$ & Lin et al., 2021 \\
\hline $\mathrm{Cd}$ & $\begin{array}{l}\text { Micrococcus sp., } \\
\text { Arthrobacter sp. }\end{array}$ & $\begin{array}{l}\text { Chlorophytum } \\
\text { amaniense, C. } \\
\text { comosum }\end{array}$ & $\begin{array}{l}\text { Micrococcus sp. increased the production of } \\
\text { biomass of both plants. Both the bacterial strains } \\
\text { boost phytoextraction of } \mathrm{Cd} \text {. }\end{array}$ & $\begin{array}{l}\text { Sangsuwan and Prapagdee, } \\
2021\end{array}$ \\
\hline $\mathrm{Cu}$ & $\begin{array}{l}\text { Pseudomonas sp. TR15a, } \\
\text { Bacillus aerophilus TR15c }\end{array}$ & Helianthus annuus & $\begin{array}{l}\text { The consortium of bacteria significantly increased } \\
\text { the dry biomass, germination, root and shoot } \mathrm{Cu} \\
\text { accumulation by } 64,32,47 \text { and } 75 \% \text {, respectively. }\end{array}$ & Kumar et al., 2021b \\
\hline $\mathrm{Cu}, \mathrm{Cd}, \mathrm{Pb}$, and $\mathrm{Zn}$ & $\begin{array}{l}\text { Bacillus subtilis, Bacillus } \\
\text { licheniformis - BC } \\
\text { Streptomyces pactum } \\
\text { Act12 -ACT }\end{array}$ & Brassica juncea & $\begin{array}{l}\text { Co-inoculation of bacteria increased the enzyme } \\
\text { activity, metal bioavailability, plant growth and } \\
\text { phytoextraction capacity of } B \text {. juncea. }\end{array}$ & Jeyasundar et al., 2021 \\
\hline $\mathrm{Cd}$ & $\begin{array}{l}\text { Lelliottia jeotgali MR2, } \\
\text { Klebsiella michiganensis } \\
\text { TS8 }\end{array}$ & Miscanthus floridulus & $\begin{array}{l}\text { Strain TS8 enhanced plant growth and declines } \\
\text { the total Cd in the rhizosphere, while MR2 } \\
\text { significantly increased the translocation of Cd from } \\
\text { root to shoot parts. }\end{array}$ & Liu et al., 2021a \\
\hline $\mathrm{Cu}, \mathrm{Cd}, \mathrm{Pb}$, and $\mathrm{Zn}$ & $\begin{array}{l}\text { Bacillus cereus } \\
\text { MG257494.1, Alcaligenes } \\
\text { faecalis MG966440.1 } \\
\text { Alcaligenes faecalis } \\
\text { MG257493.1 }\end{array}$ & Sorghum vulgare & $\begin{array}{l}\text { The bacteria consortium increased the microbial } \\
\text { activity and reduced metal bioaccumulation in the } \\
\text { plant and its root. It also controlled the metals } \\
\text { bioaccumulation factor (BAF) in plants and the } \\
\text { rhizosphere. }\end{array}$ & Abou-Aly et al., 2021 \\
\hline $\mathrm{Cd}, \mathrm{Pb}$, and $\mathrm{Cr}$ & $\begin{array}{l}\text { Pseudomonas putida } \\
\text { RE02 }\end{array}$ & Trifolium repens & $\begin{array}{l}\text { The inoculation RE02 improved the seed } \\
\text { germination tailing, soil fertility and the uptake of } \\
\text { total heavy metal by } 30.03-574.58 \% \text {. }\end{array}$ & Liu et al., 2021b \\
\hline $\mathrm{Cd}$ and $\mathrm{Mn}$ & Enterobacter sp. FM-1 & $\begin{array}{l}\text { Polygonum } \\
\text { lapathifolium L. } \\
\text { Polygonum hydropiper } \\
\text { L. }\end{array}$ & $\begin{array}{l}\text { Inoculation of bacteria increased soil bioavailability } \\
\text { of } \mathrm{Cd} \text { and } \mathrm{Mn} \text { significantly and lowered the soil } \\
\mathrm{pH} \text {, resulting in an increase in metal accumulation } \\
\text { in both the plants. }\end{array}$ & Li et al., 2020 \\
\hline $\mathrm{Sb}$ & Pseudomonas fuorescens & Trifolium repens & $\begin{array}{l}\text { The application PGPB with nZVI significantly } \\
\text { enhanced Sb accumulation capacity of } T \text {. repens. }\end{array}$ & Zand et al., 2020 \\
\hline As & $\begin{array}{l}\text { Cupriavidus basilensis } \\
\text { r507 }\end{array}$ & Pteris vittate & $\begin{array}{l}\text { P. vittata accumulated up to } 171 \% \text { of As, when } \\
\text { inoculated with the bacterial strain. }\end{array}$ & Yang et al., 2020 \\
\hline $\mathrm{Pb}$ & Micrococcus luteus & Chromolaena odorata & $\begin{array}{l}\text { M. luteus inoculated with } \mathrm{C} \text {. odorata can } \\
\text { be applied to remediate the moderately } \mathrm{Pb} \text {-fuel oil } \\
\text { contaminated mild saline soil. }\end{array}$ & Jampasri et al., 2020 \\
\hline As & Bacillus sp. XZM & $\begin{array}{l}\text { Vallisneria } \\
\text { denseserrulata }\end{array}$ & $\begin{array}{l}\text { The symbiosis between the plant and bacteria } \\
\text { significantly enhanced As uptake and removal } \\
\text { capacity. In addition, } 85 \% \text { arsenic found as As (III) } \\
\text { and }>77 \% \text { stored in vacuole of leaves cells. }\end{array}$ & Irshad et al., 2020 \\
\hline $\mathrm{Al}$ & Chaetomium cupreum & Miscanthus sinensis & $\begin{array}{l}\text { The bacteria produced siderophore called } \\
\text { oosporein that supports seedling growth and } \\
\text { increased Al tolerance and accumulation. }\end{array}$ & Haruma et al., 2019 \\
\hline As & $\begin{array}{l}\text { Azospirillum brasilense } \\
\text { Az39, Bradyrhizobium } \\
\text { japonicum E109 }\end{array}$ & Glycine max & $\begin{array}{l}\text { The mortality of plants reduced with an increase in } \\
\text { plant growth, nodule number and nitrogen } \\
\text { content. As translocation to aerial parts also } \\
\text { decreased, thus it enhances the phytostabilization } \\
\text { potential of G. max. }\end{array}$ & Armendariz et al., 2019 \\
\hline $\mathrm{Cd}, \mathrm{Pb} \mathrm{Cr}, \mathrm{Cu}$, and $\mathrm{Zn}$ & $\begin{array}{l}\text { Mesorhizobium loti } \\
\text { HZ76, Ensifer adhaerens } \\
\text { HZ14, Rhizobium } \\
\text { radiobacter HZ6 }\end{array}$ & Robinia pseudoacacia & $\begin{array}{l}\text { Treatment with } M \text {. loti } \mathrm{HZ} 76 \text { results in significantly } \\
\text { increased nodule number. Overall, the addition of } \\
\text { bacteria strains enhanced the phytoremediation } \\
\text { efficiency. }\end{array}$ & Fan et al., 2018 \\
\hline
\end{tabular}


TABLE 5 | Continued

\begin{tabular}{|c|c|c|c|c|}
\hline Targeted heavy metal & Microorganisms used & Host plant & Remarks & References \\
\hline \multirow[t]{2}{*}{$\mathrm{Pb}$ and $\mathrm{U}$} & $\begin{array}{l}\text { Enterobacter sp. HU38, } \\
\text { Pantoea stewartii ASI11, }\end{array}$ & Leptochloa fusca & $\begin{array}{l}\text { The bacterial consortia increased metal } \\
\text { accumulation capacity by 58-97\% and 53-88\% }\end{array}$ & Ahsan et al., 2017 \\
\hline & HU33 & & & \\
\hline \multicolumn{5}{|l|}{ Fungi } \\
\hline Cd and Zn & $\begin{array}{l}\text { Rhizophagus irregularis } \\
\text { (FR717169) }\end{array}$ & Phragmites australis & $\begin{array}{l}\text { Under Zn stress, the fungi helped increase the } \\
\text { activities of ascorbate peroxidase (APX) and SOD. } \\
\text { Under Cd stress, CAT, peroxidase (POD), SOD } \\
\text { and APX increased significantly. The translocation } \\
\text { factor of Zn and Cd reduced by } 10-57 \text { and } 17- \\
40 \% \text {, respectively. }\end{array}$ & You et al., 2021 \\
\hline $\mathrm{Cd}$ & $\begin{array}{l}\text { Blastocladiomycota, } \\
\text { Chytridiomycota, } \\
\text { Mortiriellomycota, } \\
\text { Tilletiopsis, } \\
\text { Sporobolomyces, } \\
\text { Cryptococcus, } \\
\text { Conocytes, Umbilicaria, } \\
\text { Amanita, Xylaria, Cirrenalia }\end{array}$ & Salix & $\begin{array}{l}\text { The presence of fungi showed a positive } \\
\text { correlation with Cd accumulation. The study } \\
\text { recorded that a higher fungal number contributes } \\
\text { to high biomass. }\end{array}$ & Wang et al., 2021 \\
\hline La & $\begin{array}{l}\text { Claroideoglomus } \\
\text { etunicatum }\end{array}$ & Zea mays & $\begin{array}{l}\text { The AMF promoted nutrient uptake and growth of } \\
\text { Z. mays in various La stressed soil. It also } \\
\text { increased the root and shoot fresh and dry weight } \\
\text { significantly. The shoot concentration of La decline } \\
\text { significantly by } 51.53 \% \text { and increased root } \\
\text { concentration by } 30.45 \% \text {. }\end{array}$ & Hao et al., 2021 \\
\hline $\mathrm{Cr}$ & Rhizophagus irregularis & Brachiaria mutica & $\begin{array}{l}\text { AMF enhanced the photosynthetic performance } \\
\text { by increasing the chlorophyll, carotenoid, proline, } \\
\text { protein content and activities of antioxidant } \\
\text { enzymes. It also improves the tolerance index, } \\
\text { transportation index and bioconcentration factor } \\
\text { of } B \text {. mutica. }\end{array}$ & Kullu et al., 2020 \\
\hline $\mathrm{Hg}$ & $\begin{array}{l}\text { Aspergillus sp. A31, } \\
\text { Lindgomycetaceae P87, } \\
\text { Curvularia geniculata P1 } \\
\text { and Westerdykella sp. P71 }\end{array}$ & $\begin{array}{l}\text { Aeschynomene } \\
\text { fluminensis, Zea mays }\end{array}$ & $\begin{array}{l}\text { The tolerance capacity of plants for the } \mathrm{Hg}^{2+} \text { was } \\
\text { improved after the inoculation of fungi. The } \\
\text { biomass of the plants increased along with the } \\
\text { reduction in soil } \mathrm{Hg} \text { concentration. Further, the soil } \\
\text { Hg level reduced in } A \text {. fluminensis by } 57.14 \% \\
\text { inoculated with P87. }\end{array}$ & Pietro-Souza et al., 2020 \\
\hline \multirow[t]{2}{*}{ As } & 21 fungal strains including & Bacopa monnieri & Humicola sp. enhanced the plant growth and & Tripathi et al., 2020 \\
\hline & Humicola sp. & & $\begin{array}{l}\text { bacoside content and can use as a realistic and } \\
\text { potential mitigation strategy for reducing the As } \\
\text { level in the cropping system. }\end{array}$ & \\
\hline As & Piriformospora indica & Artemisia annua & $\begin{array}{l}\text { The inoculation of fungi helped the plant to } \\
\text { accumulate significantly high concentration of As } \\
\text { in roots than shoots. In addition, overall biomass, } \\
\text { artemisinin, flavonoids, peroxidase and SOD were } \\
\text { increased significantly. }\end{array}$ & $\begin{array}{l}\text { Saeed-ur-Rahman et al., } \\
2020\end{array}$ \\
\hline
\end{tabular}


TABLE 5 | Continued

\begin{tabular}{|c|c|c|c|c|}
\hline Targeted heavy metal & Microorganisms used & Host plant & Remarks & References \\
\hline $\mathrm{Cd}, \mathrm{Pb}$, and $\mathrm{Zn}$ & $\begin{array}{l}\text { Cenococcum geophilum } \\
\text { (Cg, KY075873.1), } \\
\text { Laccaria sp. (L1, } \\
\text { KY075876.1,), Pisolithus } \\
\text { sp.1 (P1, KY075877.1), } \\
\text { Pisolithus sp. } 2 \text { (P2, } \\
\text { MN422052) }\end{array}$ & Pinus sylvestris & $\begin{array}{l}\text { Inoculation of fungi increased the survival rates of } \\
\text { plants by enhancing the biomass, photosynthetic } \\
\text { rate, transpiration rate, stomatal conductance, } \\
\text { mineral nutrients and intercellular } \mathrm{CO}_{2} \\
\text { concentration. Further, } \mathrm{P} \text {. sylvestris accumulated a } \\
\text { higher concentration of } \mathrm{Cd} \text {, Pb and } \mathrm{Zn} \text { than non- } \\
\text { ectomycorrhizal seedlings. }\end{array}$ & Liu et al., 2020 \\
\hline As & Rhizophagus, Funelliformis & Pteris vittata & $\begin{array}{l}\text { Rhizophagus and Funelliformis inoculation } \\
\text { improved the plant growth and increased the fresh } \\
\text { and dry weight of aerial parts by } 44 \text { and } 37 \% \text {, } \\
\text { respectively. The BAF for inoculated plants was } \\
7.6 \text { while for uninoculated it was recorded 6.0. }\end{array}$ & Cantamessa et al., 2020 \\
\hline $\mathrm{Cd}$ and $\mathrm{Pb}$ & $\begin{array}{l}\text { Simplicillium chinense } \\
\text { QD10 }\end{array}$ & Phragmites communis & $\begin{array}{l}\text { The amendments of } S \text {. chinense QD10 } \\
\text { significantly increased the phytoextraction of metal } \\
\text { by } 28.6-48.0 \% \text { of } P \text {. communis. }\end{array}$ & Jin et al., 2019 \\
\hline $\mathrm{Cd}$ & $\begin{array}{l}\text { Acaulospora } \\
\text { Laevis, Glomus } \\
\text { monosporum, G. clarum, } \\
\text { Gigaspora nigra }\end{array}$ & $\begin{array}{l}\text { Trigonella } \\
\text { foenumgraecum }\end{array}$ & $\begin{array}{l}\text { Inoculation of AMF enhanced the plant growth } \\
\text { parameters, protein and chlorophyll contents. The } \\
\text { TF of plants was also reduced significantly. }\end{array}$ & $\begin{array}{l}\text { Abdelhameed and Metwally, } \\
2019\end{array}$ \\
\hline
\end{tabular}

\section{FACTORS AFFECTING BIOREMEDIATION EFFICIENCY}

The most important factor affecting bioremediation efficiency is site characteristics. Secondly, environmental factors such as water content, temperature, $\mathrm{pH}$, nutrient availability, moisture content, and pollutant bioavailability can also hinder the efficiency of bioremediation (Freitas et al., 2013; Azubuike et al., 2016; Khodaverdiloo et al., 2020; Leong and Chang, 2020). Apart from this, the bioremediation process is a complex system that is optimized and controlled by many factors. The interactions among the contaminants, microbes, nutrient availability and environmental factors affect the bioavailability and biodegradation of the contaminants.

\section{Site Characteristics}

The first and most important factors which affect the bioremediation process are the site location and its characteristics. The extent and type of contaminants present in the location determine the remediation efficiency (Abatenh et al., 2017). These factors can be overcome and managed by sufficient prior investigation and characterization of sites before implementing the remediation process.

\section{Temperature}

Temperature is an important factor that determines the survival and growth of the microorganism and the composition of hydrocarbon (Yang et al., 2009). It plays a critical role in the microbe-assisted remediation process by affecting both the physical and chemical states of contaminants present in the polluted sites and interrupting the microbial metabolisms, growth rate, soil matrix, and gas solubilities (Megharaj et al., 2011). It is recorded that high temperature destroys the cell metabolic activity of bacteria and affects the process of bioaccumulation (Javanbakht et al., 2014). Furthermore, the temperature can speed up or slow down the remediation process as microbial physiological properties are highly influenced by temperature. The interaction between fungal membrane binding sites and heavy metal ions depends on the temperature. Temperature also affects the configuration and stability of fungal membrane by chemical moieties ionization (Oka et al., 2005). Jin et al. (2019) showed that the biosorption efficiency of $S$. chinense QD10 for $\mathrm{Cd}$ and $\mathrm{Pb}$ was highest at $30^{\circ} \mathrm{C}$ by 60.4 and $38.3 \%$, respectively. But it significantly declined when the temperature increased to $45^{\circ} \mathrm{C}$. The microbial adsorption is also affected by temperature (Timková et al., 2018).

\section{$\mathrm{pH}$}

pH has its own impacts on the metabolic activity of microorganisms which can increase or decrease the removal process. Bioremediation can be applied in a wide range of $\mathrm{pH}$. However, a $\mathrm{pH}$ of 6.5 to 8.5 is considered the maximum potential for remediating the most terrestrial and aquatic systems (Abatenh et al., 2017). The $\mathrm{pH}$ value influences the biosorption process by dissociation of functional groups on the fungal membrane and affects heavy metal mobility and solubility (Wang et al., 2014). It was observed that the Cd biosorption capacity of Exiguo bacterium sp. enhanced with increased $\mathrm{pH}$ up to 7.0 and remained neutral when the $\mathrm{pH}$ was higher than 7.0 (Park and Chon, 2016). The microbial adsorption is also affected $\mathrm{pH}$ and ionic strength (Timková et al., 2018).

\section{Nutrient Availability}

Likewise, nutrient concentration, availability, and type are also important for microbial growth and activity in the bioremediation process. The fundamental elements (such as carbon, nitrogen, and phosphorous) help the microbes produce the necessary enzymes to break down the pollutants. The lower level of nutrient availability affects the plant and microorganisms, which ultimately affects the bioremediation rate and effectiveness. In this condition balancing the essential 
nutrient such as nitrogen $(\mathrm{N})$ and phosphorus $(\mathrm{P})$ can enhance the bioremediation efficacy through optimizing the bacterial C:N:P ratio (Abatenh et al., 2017). In the colder environment, the supply of an appropriate quantity of nutrients enhances the metabolic activity of microorganisms, which leads to an increase in the remediation rate (Phulia et al., 2013; Couto et al., 2014). It has been reported that an excessive amount of nitrogen in the contaminated medium resulted in microbial inhabitation (Varjani and Upasani, 2017). Further, the higher concentration of nitrogen, phosphorus, and potassium hinders the biodegradation efficiency of hydrocarbon contaminants.

\section{Moisture Content}

The microorganisms can be adversely affected by the soil moisture content. Moisture affects the rate of pollutant metabolism via influencing the amount and type of soluble materials as well as the $\mathrm{pH}$ and osmotic pressure of the terrestrial and aquatic sites (Abatenh et al., 2017).

\section{Type/Nature of Microorganism and Plant}

The existence of unsuitable microorganisms or the inadequate presence of suitable microorganisms in the contaminated sites affects the bioremediation efficiency. Apart from this, the microbial biophysical process also influences bioaccumulation as the process is metabolically dependent and uses cellular energy for metal uptake. It depends on the microbial biochemical features, genetic and physiological ability, internal structure, cell surface properties such as charge changes, and surrounding environmental conditions (Srinath et al., 2002; Vijayaraghavan and Yun, 2008; Issazadeh et al., 2013). Razmi et al. (2021) found that phytoremediation efficiency was influenced by various biological and chemical factors. For the plant-based remediation, the important factors consider for selecting the suitable plants includes the root system, it may be tap or fibrous roots depending on the depth of the contaminants, above-ground biomass, which should not preferable for livestock consumption, survival, and adaptation of plants and the plant growth (Azubuike et al., 2016). However, the role of plant type in the phytoremediation of $\mathrm{Cd}, \mathrm{Pb}, \mathrm{Ni}$, and $\mathrm{Zn}$ has been considered as the prime factor. Similarly, the maximum biosorption efficiency for most of the fungal strains was found under their optimal growth conditions (Iram et al., 2015).

\section{Water Content}

In general, microorganisms require water activity values between 0.9-1.0 for metabolism and growth. Most of the bacteria grow optimally at the upper limits of water activity values (Sharma, 2019). Therefore, the water content in contaminated land is an essential factor that may affect the bioremediation rate. Recently, Khodaverdiloo et al. (2020) highlighted that water deficiency, sodicity, and salinity are also important factors that affect bioremediation efficiency.

\section{Pollutant Bioavailability}

The low bioavailability of HMs in the contaminated soil greatly affected the bioremediation efficiency. The bioavailability of contaminants is controlled by various physicochemical processes such as sorption, diffusion, desorption, and dissolution. This problem can be managed using various surfactants and chelating agents, which enhance the bioavailability of HMs for microbial degradation and plant uptake. Various types of organic and inorganic chelating agents are applied recently such as ethylenediamine tetraacetic acid (EDTA), [S,S]-ethylenediaminedisuccinic acid (EDDS), ethylenediamine-di-ohydroxyphenylacetic acid (EDDHA), diethylenetriaminepentaacetic acid (DTPA), nhydroxyethylenediaminetriacetic acid (HEDTA) citric acid, acetic acid, and malic acid. Application of these chelating agents has successfully proven that it effectively forms a complex with HMs and increases the bioavailability (Sarwar et al., 2017).

\section{CHALLENGES AND FUTURE PROSPECTS}

The bioremediation methods are diverse and show effectiveness in restoring the polluted sites contaminated with multiple HMs. However, there are some important factors to be considered before implementing bioremediation practices. There is a need for regular investigation and assessment of the level of HMs and other pollutant concentrations in the contaminated sites before proposing bioremediation. The selection of an appropriate type of microbes and plant species is a very hefty task for the sites where the presence of multi-metals and other organic pollutants at the same site. Secondly for the plant-based bioremediation, the presence of volatile metals and metalloids such as $\mathrm{Si}, \mathrm{Hg}$, and $\mathrm{As}$ in the site may get volatilized into the atmosphere in their toxic form which may affect the living organisms. Third, if edible plants are used for bioremediation purposes, there is a risk that they can be consumed by animals, insects and which may further contaminate the food chain and ultimately reach humans and cause serious health complications. For this, nonedible and nonpalatable phytoremediator plant species can be preferred or in the case of the edible plants, proper protection during cultivation, and harvesting must be taken to avoid future complications. With the presence HMs deeper into the ground where plant roots cannot reach, in situ phytoremediation becomes difficult.

Further research, assessment, and investigation are required to enhance our knowledge and understanding of best management practices for efficient bioremediation of HMs. There is a need for futuristic clarification of mechanisms, metabolites, and novel approaches/methods are required. For simple and efficient plantbased bioremediation, utilization of hyperaccumulator plants to efficiently remove of HMs from the contaminated soil need novel strategies for its further progress. This can be achieved in two ways, first by finding and validating the various diversity of new hyperaccumulator plant species, and second by developing the hyperaccumulator plant using genetic engineering. In addition, we can consider the hyperaccumulator plants with deep root plants for, e.g., woody plants or tree such as Populus $\times$ canescens, Rinorea bengalensis, Schima superba and Pycnandra acuminata with high translocation rate, high biomass and growth rates and more tolerant plant species.

Biotechnological intervention including genetic engineering, for example, the rate-limiting step in a known metabolic pathway 
can be manipulated genetically to enhance the transfer and biodegradation rates, or by introducing a completely new metabolic pathway into the microbe for higher accumulation of HMs or degradation of recalcitrant compounds. In addition, overexpression of foreign genes into a non-tolerant plant with having higher biomass for HM remediation from the soil may be a feasible strategy. The advanced way to study hologenomics of plants microorganism will be helpful for the manipulation of microbial niches which help to enhance the resistance against toxic metal contamination. For multi-metal contaminated and multi-stress environmental conditions, there is a need to development of suitable amendments to enhance the survival of the suitable plant species. Although there are several organic and inorganic amendments and metal chelators are available there is a need for further investigation to find out more suitable and eco-friendly amendments which can be applied for the treatment of multimetal contaminated and multi-stressed soil. There is a necessity for coordination and contribution of researchers, scientists, policymakers, government, industrial sectors, and individuals that can help to success and reliability of bioremediation.

\section{CONCLUSION}

Man-made activities have been introducing a high amount of toxic metals into the environment, affecting the life processes of all living organisms in direct and indirect ways. It has been reported that more than one type of heavy metal is simultaneously present in the contaminated land and the available conventional methods are not significantly efficient to detoxify the pollutants compared to the bioremediation process. It has been proved that bioremediation methods are easily affordable compared to other physicochemical remediation techniques. A number of bacterial and fungal strains have been isolated and identified from different metal-contaminated and mining abandoned soils in recent years. Pseudomonas spp., Bacillus spp., Aspergillus spp., and Penicillium spp. are found frequently and show high metal tolerance and bioremediation potential. Currently, bioremediation has been practiced in various contaminated sites globally with varying

\section{REFERENCES}

Abatenh, E., Gizaw, B., Tsegaye, Z., and Wassie, M. (2017). The role of microorganisms in bioremediation- A review. Open J. Environ. Biol. 2, 38-46. doi: $10.17352 /$ ojeb.000007

Abdelhameed, R. E., and Metwally, R. A. (2019). Alleviation of cadmium stress by arbuscular mycorrhizal symbiosis. Int. J. Phytoremediation 21, 663-671. doi: 10.1080/15226514.2018.1556584

Abou-Aly, H. E., Youssef, A. M., Tewfike, T. A., El-Alkshar, E. A., and El-Meihy, R. M. (2021). Reduction of heavy metals bioaccumulation in sorghum and its rhizosphere by heavy metals-tolerant bacterial consortium. Biocatal. Agric. Biotechnol. 31:101911. doi: 10.1016/j.bcab.2021. 101911

Acheampong, M. A., Meulepas, R. J. W., and Lens, P. N. L. (2010). Removal of heavy metals and cyanide from gold mine wastewater. J. Chem. Technol. Biotechnol. 85, 590-613. doi: 10.1002/jctb.2358

Acuña, E., Castillo, B., Queupuan, M., Casanova, M., and Tapia, Y. (2020). Assisted phytoremediation of lead contaminated soil using Atriplex halimus and its effect on some soil physical properties. Int. J. Environ. Sci. Technol. 18, 1925-1938. doi: 10.1007/s13762-020-02978-5 degrees of success. Recently by applying the various plants and microorganisms to remediate the contaminants from the environment has been noted like Alaska oil spill remediation, China's Aleutian island bioremediation operation and other decontamination cases of HMs from the industrial and agricultural fields. The addition of proper supplements and enhancing environmental conditions are the prime concern for the significant yield of bioremediation. To overcome the above problem, the addition of organic matter and a consortium of microorganisms can enhance microbial metabolic activity and may improve bioremediation potential. In addition, more investigations are still required to screen the more suitable microorganisms, hyperaccumulator plants that will have a high capacity to tolerate multi-metal contaminated and multi-stress environmental conditions sites and accumulate multi-metals at once. Further attention will be required to plant-microbe-based bioremediation strategies to identify the novel plant-microbe pairs that will have high metal removal efficiency along with creating a favorable environment to accommodate other microbial diversity for indirectly improving the soil health. Additionally, further research on the application of nanomaterials and biochar along with microbes to enhance bioremediation efficiency is needed.

\section{AUTHOR CONTRIBUTIONS}

All authors listed have made a substantial, direct and intellectual contribution to the work, and approved it for publication.

\section{FUNDING}

This work is carried out at the College of Resources and Environment, Southwest University, supported by the Fundamental Research Funds for the Central Universities (No. SWU 020010), the Natural Science Foundation of Chongqing (No. cstc2021jcyj-msxmX0827) and Chongqing Returned Overseas Students' Entrepreneurship and Innovation Support Program (No. cx2021001).

Aguilar, N. C., Faria, M. C., Pedron, T., Batista, B. L., Mesquita, J. P., Bomfeti, C. A., et al. (2020). Isolation and characterization of bacteria from a brazilian gold mining area with a capacity of arsenic bioaccumulation. Chemosphere 240:124871. doi: 10.1016/j.chemosphere.2019.124871

Ahemad, M. (2019). Remediation of metalliferous soils through the heavy metal resistant plant growth promoting bacteria: paradigms and prospects. Arab. J. Chem. 12, 1365-1377. doi: 10.1016/j.arabjc.2014.11.020

Ahern, M., Mullett, M., MacKay, K., and Hamilton, C. (2011). Residence in coal-mining areas and low-birth-weight outcomes. Matern. Child Health J. 15, 974-979. doi: 10.1007/s10995-009-0555-1

Ahsan, M. T., Najam-ul-Haq, M., Idrees, M., Ullah, I., and Afzal, M. (2017). Bacterial endophytes enhance phytostabilization in soils contaminated with uranium and lead. Int. J. Phytoremediation 19, 937-946. doi: 10.1080/ 15226514.2017.1303813

Akhter, K., Ghous, T., Ul-Abdin, Z., Andleeb, S., Ahmed, M. N., and Hussain, B. (2020). Chromium bioaccumulation potential of Bacillus cereus isolated from rhizospheres of Tagetes minuta L. Bangladesh J. Bot. 49, 47-54. doi: 10.3329/ bjb.v49i1.49091

Akkoyun, M. B., Özdemir, S., Kılınç, E., and Birhanlı, E. (2020b). Investigations of $\mathrm{Hg}$ (II) and $\mathrm{Pb}$ (II) tolerance, removal and bioaccumulation and their 
effects on antioxidant enzymes on thermophilic Exiguobacterium profundum. Hum. Ecol. Risk. Assess. 26, 1234-1253. doi: 10.1080/10807039.2018.1562882

Akkoyun, M. B., Ozdemir, S., Kilinc, E., Birhanli, E., Aygün, A., and Sen, F. (2020a). Resistance, removal, and bioaccumulation of Ni (II) and Co (II) and their impacts on antioxidant enzymes of Anoxybacillus mongoliensis. Comp. Biochem. Physiol. C Toxicol. Pharmacol. 235:108790. doi: 10.1016/j. cbpc. 2020.108790

Ali, H., Khan, E., and Sajad, M. A. (2013). Phytoremediation of heavy metals concepts and applications. Chemosphere 91, 869-881. doi: 10.1016/j. chemosphere.2013.01.075

Ameen, F. A., Hamdan, A. M., and El-Naggar, M. Y. (2020). Assessment of the heavy metal bioremediation efficiency of the novel marine lactic acid bacterium, lactobacillus plantarum MF042018. Sci. Rep. 10, 1-11. doi: 10.1038/ s41598-019-57210-3

Armendariz, A. L., Talano, M. A., Nicotra, M. F. O., Escudero, L., Breser, M. L., Porporatto, C., et al. (2019). Impact of double inoculation with Bradyrhizobium japonicum E109 and Azospirillum brasilense Az39 on soybean plants grown under arsenic stress. Plant Physiol. Biochem. 138, 26-35. doi: 10.1016/j. plaphy.2019.02.018

Arshad, M., Saleem, M., and Hussain, S. (2007). Perspectives of bacterial ACC deaminase in phytoremediation. Trends Biotechnol. 25, 356-362. doi: 10.1016/j. tibtech.2007.05.005

Aslam, F., Yasmin, A., and Sohail, S. (2020). Bioaccumulation of lead, chromium, and nickel by bacteria from three different genera isolated from industrial effluent. Int. Microbiol. 23, 253-261. doi: 10.1007/ s10123-019-00098-w

Atagana, H. I., Haynes, R. J., and Wallis, F. M. (2003). Optimization of soil physical and chemical conditions for the bioremediation of creosotecontaminated soil. Biodegradation 14, 297-307. doi: 10.1023/A:1024730722751

Atigh, Z. B. Q., Heidari, A., Sepehr, A., Bahreini, M., and Mahbub, K. R. (2020). Bioremediation of heavy metal contaminated soils originated from iron ore mine by bio-augmentation with native cyanobacteria. Iran. J. Energy Environ. 11, 89-96. doi: 10.5829/IJEE.2020.11.02.01

Atteia, O., and Guillot, C. (2007). Factors controlling BTEX and chlorinated solvents plume length under natural attenuation conditions. J. Contam. Hydrol. 90, 81-104. doi: 10.1016/j.jconhyd.2006.09.012

Ayangbenro, A. S., and Babalola, O. O. (2017). A new strategy for heavy metal polluted environments: a review of microbial biosorbents. Int. J. Environ. Res. Public Health. 14:94. doi: 10.3390/ijerph14010094

Azubuike, C. C., Chikere, C. B., and Okpokwasili, G. C. (2016). Bioremediation techniques-classification based on site of application: principles, advantages, limitations and prospects. World J. Microbiol. Biotechnol. 32:180. doi: 10.1007/ s11274-016-2137-x

Balzano, S., Sardo, A., Blasio, M., Chahine, T. B., Dell'Anno, F., Sansone, C., et al. (2020). Microalgal metallothioneins and phytochelatins and their potential use in bioremediation. Front. Microbiol. 11:517. doi: 10.3389/ fmicb.2020.00517

Banerjee, S., Misra, A., Chaudhury, S., and Dam, B. (2019). A Bacillus strain TCL isolated from Jharia coalmine with remarkable stress responses, chromium reduction capability and bioremediation potential. J. Hazard. Mater. 367, 215-223. doi: 10.1016/j.jhazmat.2018.12.038

Bauddh, K., and Singh, R. P. (2012). Growth, tolerance efficiency and phytoremediation potential of Ricinus communis (L.) and Brassica juncea (L.) in salinity and drought affected cadmium contaminated soil. Ecotoxicol. Environ. Saf. 85, 13-22. doi: 10.1016/j.ecoenv.2012.08.019

Bauddh, K., and Singh, R. P. (2015). Assessment of metal uptake capacity of castor bean and mustard for phytoremediation of nickel from contaminated soil. Biorem. J. 19, 124-138. doi: 10.1080/10889868.2014.979277

Bernhoft, R. A. (2012). Mercury toxicity and treatment: a review of the literature. J. Environ. Public Health 2012:460508. doi: 10.1155/2012/460508

Bhattacharyya, P., and Jha, D. (2012). Plant growth-promoting rhizobacteria (PGPR): emergence in agriculture. World J. Microbiol. Biotechnol. 28, 1327-1350. doi: 10.1007/s11274-011-0979-9

Bilal, S., Shahzad, R., Imran, M., Jan, R., Kim, K. M., and Lee, I. J. (2020). Synergistic association of endophytic fungi enhances Glycine max L. resilience to combined abiotic stresses: heavy metals, high temperature and drought stress. Ind. Crop. Prod. 143:111931. doi: 10.1016/j.indcrop.2019.111931

Biswal, B., Singh, S. K., Patra, A., and Mohapatra, K. K. (2021). Evaluation of phytoremediation capability of French marigold (Tagetes patula) and
African marigold (Tagetes erecta) under heavy metals contaminated soils. Int. J. Phytoremediation, 1-10. doi: 10.1080/15226514.2021.1985960

Blaylock, M. J., Salt, D. E., Dushenkov, S., Zakharova, O., Gussman, C., Kapulnik, Y., et al. (1997). Enhanced accumulation of $\mathrm{Pb}$ in Indian mustard by soil-applied chelating agents. Environ. Sci. Technol. 31, 860-865. doi: 10.1021/es960552a

Bruno, L. B., Anbuganesan, V., Karthik, C., Kumar, A., Banu, J. R., Freitas, H., et al. (2021). Enhanced phytoextraction of multi-metal contaminated soils under increased atmospheric temperature by bioaugmentation with plant growth promoting Bacillus cereus. J. Environ. Manag. 289:112553. doi: 10.1016/j. jenvman.2021.112553

Cantamessa, S., Massa, N., Gamalero, E., and Berta, G. (2020). Phytoremediation of a highly arsenic polluted site, using Pteris vittata L. and Arbuscular Mycorrhizal fungi. Plan. Theory 9:1211. doi: 10.3390/plants9091211

Caporale, A. G., and Violante, A. (2016). Chemical processes affecting the mobility of heavy metals and metalloids in soil environments. Curr. Pollut. Rep. 2, 15-27. doi: 10.1007/s40726-015-0024-y

Chakraborty, R., Wu, C. H., and Hazen, T. C. (2012). Systems biology approach to bioremediation. Curr. Opin. Biotechnol. 23, 483-490. doi: 10.1016/j. copbio.2012.01.015

Chandra, S. P., Sanyal, D., Dasgupta, S., and Banik, A. (2020). Cadmium biosorption and biomass production by two freshwater microalgae Scenedesmus acutus and Chlorella pyrenoidosa: An integrated approach. Chemosphere 269:128755. doi: 10.1016/j.chemosphere.2020.128755

Chang, J., Shi, Y., Si, G., Yang, Q., Dong, J., and Chen, J. (2020). The bioremediation potentials and mercury (II)-resistant mechanisms of a novel fungus Penicillium spp. DC-F11 isolated from contaminated soil. J. Hazard. Mater. 396:122638. doi: $10.1016 /$ j.jhazmat.2020.122638

Chaturvedi, R., Favas, P. J., Pratas, J., Varun, M., and Paul, M. S. (2021). Harnessing Pisum sativum-Glomus mosseae symbiosis for phytoremediation of soil contaminated with lead, cadmium, and arsenic. Int. J. Phytoremediation 23, 279-290. doi: 10.1080/15226514.2020.1812507

Chen, J., Li, N., Han, S., Sun, Y., Wang, L., Qu, Z., et al. (2020). Characterization and bioremediation potential of nickel-resistant endophytic bacteria isolated from the wetland plant Tamarix chinensis. FEMS Microbiol. Lett. 367:fnaa098. doi: 10.1093/femsle/fnaa098

Chen, L., Long, C., Wang, D., and Yang, J. (2020a). Phytoremediation of cadmium (Cd) and uranium (U) contaminated soils by Brassica juncea L. enhanced with exogenous application of plant growth regulators. Chemosphere 242:125112. doi: $10.1016 /$ j.chemosphere.2019.125112

Chen, Y., Yang, W., Chao, Y., Wang, S., Tang, Y. T., and Qiu, R. L. (2017). Metal-tolerant Enterobacter sp. strain EG16 enhanced phytoremediation using Hibiscus cannabinus via siderophore-mediated plant growth promotion under metal contamination. Plant Soil 413, 203-216. doi: 10.1007/ s11104-016-3091-y

Chibuike, G. U., and Obiora, S. C. (2014). Heavy metal polluted soils: effect on plants and bioremediation methods. Appl. Environ. Soil Sci. 214, 1-12. doi: $10.1155 / 2014 / 752708$

Choińska-Pulit, A., Sobolczyk-Bednarek, J., and Łaba, W. (2018). Optimization of copper, lead and cadmium biosorption onto newly isolated bacterium using a Box-Behnken design. Ecotoxicol. Environ. Saf. 149, 275-283. doi: 10.1016/j.ecoenv.2017.12.008

Coelho, L. M., Rezende, H. C., Coelho, L. M., de Sousa, P. A., Melo, D. F., and Coelho, N. M. (2015). "Bioremediation of polluted waters using microorganisms," in Advances in Bioremediation of Wastewater and Polluted Soil. ed. N. Shiomi (Shanghai, China: InTech).

Cornejo, P., Meier, S., Borie, G., Rillig, M., and Borie, F. (2008). Glomalinrelated soil protein in a Mediterranean ecosystem affected by a copper smelter and its contribution to $\mathrm{Cu}$ and $\mathrm{Zn}$ sequestration. Sci. Total Environ. 406, 154-160. doi: 10.1016/j.scitotenv.2008.07.045

Couto, N., Fritt-Rasmussen, J., Jensen, P. E., Højrup, M., Rodrigo, A. P., and Ribeiro, A. B. (2014). Suitability of oil bioremediation in an Artic soil using surplus heating from an incineration facility. Environ. Sci. Pollut. Res. 21, 6221-6227. doi: 10.1007/s11356-013-2466-3

Cui, X., Mao, P., Sun, S., Huang, R., Fan, Y., Li, Y., et al. (2021). Phytoremediation of cadmium contaminated soils by Amaranthus Hypochondriacus L.: the effects of soil properties highlighting cation exchange capacity. Chemosphere 283:131067. doi: 10.1016/j.chemosphere.2021.131067

Curaqueo, G., Schoebitz, M., Borie, F., Caravaca, F., and Roldán, A. (2014). Inoculation with arbuscular mycorrhizal fungi and addition of composted 
olive-mill waste enhance plant establishment and soil properties in the regeneration of a heavy metal-polluted environment. Environ. Sci. Pollut. Res. 21, 7403-7412. doi: 10.1007/s11356-014-2696-z

Daghan, H., Arslan, M., Uygur, V., and Loleli, N. (2013). Transformation of tobacco with ScMTII gene-enhanced cadmium and zinc accumulation. Clean (Weinh) 41, 503-509. doi: 10.1002/clen.201200298

De Quadros, P. D., Zhalnina, K., Davis-Richardson, A. G., Drew, J. C., Menezes, F. B., Flávio, A. D. O., et al. (2016). Coal mining practices reduce the microbial biomass, richness and diversity of soil. Appl. Soil Ecol. 98, 195-203. doi: 10.1016/j.apsoil.2015.10.016

Din, G., Hassan, A., Dunlap, J., Ripp, S., and Shah, A. A. (2021). Cadmium tolerance and bioremediation potential of filamentous fungus Penicillium chrysogenum FMS2 isolated from soil Int. J. Environ. Sci. Technol., 1-10. doi: 10.1007/s13762-021-03211-7

Dixit, R., Malaviya, D., Pandiyan, K., Singh, U. B., Sahu, A., Shukla, R., et al. (2015). Bioremediation of heavy metals from soil and aquatic environment: An overview of principles and criteria of fundamental processes. Sustainability. 7, 2189-2212. doi: 10.3390/su7022189

Ekperusi, O., and Aigbodion, F. (2015). Bioremediation of petroleum hydrocarbons from crude oil-contaminated soilwith the earthworm: Hyperiodrilus africanus. 3 Biotech. 5, 957-965. doi: 10.1007/s13205-015-0298-1

Fan, M., Xiao, X., Guo, Y., Zhang, J., Wang, E., Chen, W., et al. (2018). Enhanced phytoremdiation of Robinia pseudoacacia in heavy metalcontaminated soils with rhizobia and the associated bacterial community structure and function. Chemosphere 197, 729-740. doi: 10.1016/j. chemosphere.2018.01.102

Farhan, S. N., and Khadom, A. A. (2015). Biosorption of heavy metals from aqueous solutions by Saccharomyces cerevisiae. Int. J. Ind. Chem. 6, 119-130. doi: $10.1007 /$ s40090-015-0038-8

Fasani, E., Manara, A., Martini, F., Furini, A., and DalCorso, G. (2018). The potential of genetic engineering of plants for the remediation of soils contaminated with heavy metals. Plant Cell Environ. 41, 1201-1232. doi: $10.1111 /$ pce. 12963

Feng, Y., Wang, J., Bai, Z., and Reading, L. (2019). Effects of surface coal mining and land reclamation on soil properties: A review. Earth-Sci. Rev. 191, 12-25. doi: 10.1016/j.earscirev.2019.02.015

Flora, G., Gupta, D., and Tiwari, A. (2012). Toxicity of lead: a review with recent updates. Interdiscip. Toxicol. 5, 47-58. doi: 10.2478/v10102-0120009-2

Freitas, E. V., Nascimento, C. W., Souza, A., and Silva, F. B. (2013). Citric acid-assisted phytoextraction of lead: A field experiment. Chemosphere 92, 213-217. doi: 10.1016/j.chemosphere.2013.01.103

Fulekar, M. H., Sharma, J., and Tendulkar, A. (2012). Bioremediation of heavy metals using biostimulation in laboratory bioreactor. Environ. Monit. Assess. 184, 7299-7307. doi: 10.1007/s10661-011-2499-3

Ghose, M. K. (2005). Soil conservation for rehabilitation and revegetation of mine-degraded land. TERI Inf. Digest Energy Environ. 4, 137-150.

Gola, D., Dey, P., Bhattacharya, A., Mishra, A., Malik, A., Namburath, M., et al. (2016). Multiple heavy metal removal using an entomopathogenic fungi Beauveria bassiana. Bioresour. Technol. 218, 388-396. doi: 10.1016/j. biortech.2016.06.096

Gong, X., Huang, D., Liu, Y., Zeng, G., Wang, R., Wan, J., et al. (2017). Stabilized nanoscale zerovalent iron mediated cadmium accumulation and oxidative damage of Boehmeria nivea (L.) Gaudich cultivated in cadmium contaminated sediments. Environ. Sci. Technol. 51, 11308-11316. doi: 10.1021/ acs.est.7b03164

Gonzaga, M. I. S., de Jesus Santos, J. C., Ganassali Junior, L. F., Fontes, P. T. N., Araújo, J. D. S., and Gonzaga, T. A. S. (2021). Copper uptake, physiological response, and phytoremediation potential of Brassica juncea under biochar application. Int. J. Phytoremediation 5, 1-9. doi: 10.1080/15226514.2021. 1954875

González-Chávez, M. D. C. A., Carrillo-González, R., Cuellar-Sánchez, A., Delgado-Alvarado, A., Suárez-Espinosa, J., Ríos-Leal, E., et al. (2019). Phytoremediation assisted by mycorrhizal fungi of a Mexican defunct leadacid battery recycling site Sci. Total Environ. 650, 3134-3144. doi: 10.1016/j. scitotenv.2018.10.031

Goyal, D., Yadav, A., Prasad, M., Singh, T. B., Shrivastav, P., Ali, A., et al. (2020). "Effect of heavy metals on plant growth: An overview," in Contaminants in Agriculture (Cham: Springer), 79-101.
Guarino, F., Miranda, A., Castiglione, S., and Cicatelli, A. (2020). Arsenic phytovolatilization and epigenetic modifications in Arundo donax L. assisted by a PGPR consortium. Chemosphere 251:126310. doi: 10.1016/j.chemosphere. 2020.126310

Gunathilakae, N., Yapa, N., and Hettiarachchi, R. (2018). Effect of arbuscular mycorrhizal fungi on the cadmium phytoremediation potential of Eichhornia crassipes (Mart.) Solms. Groundw. Sustain. Dev. 7, 477-482. doi: 10.1016/j. gsd.2018.03.008

Gupta, P., and Diwan, B. (2016). Bacterial exopolysaccharide mediated heavy metal removal: A review on biosynthesis, mechanism and remediation strategies. Biotechnol. Rep. 13, 58-71. doi: 10.1016/j.btre.2016.12.006

Gupta, D. K., Huang, H. G., and Corpas, F. J. (2013). Lead tolerance in plants: strategies for phytoremediation. Environ. Sci. Pollut. R. 20, 2150-2161. doi: 10.1007/s11356-013-1485-4

Gupta, P., and Kumar, V. (2017). Value added phytoremediation of metal stressed soils using phosphate solubilizing microbial consortium. World J. Microbiol. Biotechnol. 33, 1-15. doi: 10.1007/s11274-016-2176-3

Gupta, C. K., and Singh, B. (2017). Uninhibited biosynthesis and release of phytosiderophores in the presence of heavy metal (HM) favors HM remediation. Environ. Sci. Pollut. Res. 24, 9407-9416. doi: 10.1007/ s11356-017-8636-y

Hao, X., Taghavi, S., Xie, P., Orbach, M. J., Alwathnani, H. A., Rensing, C., et al. (2014). Phytoremediation of heavy and transition metals aided by legume-rhizobia symbiosis. Int. J. Phytoremediation 16, 179-202. doi: $10.1080 / 15226514.2013 .773273$

Hao, L., Zhang, Z., Hao, B., Diao, F., Zhang, J., Bao, Z., et al. (2021). Arbuscular mycorrhizal fungi alter microbiome structure of rhizosphere soil to enhance maize tolerance to La. Ecotoxicol. Environ. Saf. 212:111996. doi: 10.1016/j. ecoenv.2021.111996

Hartman, W. J. Jr. (1975) An evaluation of land treatment of municipal wastewater and physical siting of facility installations. DTIC Document. Availabe at: https://apps.dtic.mil/sti/citations/ADA016118

Haruma, T., Yamaji, K., Ogawa, K., Masuya, H., Sekine, Y., and Kozai, N. (2019). Root-endophytic Chaetomium cupreum chemically enhances aluminium tolerance in Miscanthus sinensis via increasing the aluminium detoxicants, chlorogenic acid and oosporein. PLoS One 14:e0212644. doi: 10.1371/journal.pone.0212644

Hasan, M., Cheng, Y., Kanwar, M. K., Chu, X. Y., Ahammed, G. J., and Qi, Z. Y. (2017). Responses of plant proteins to heavy metal stress-a review. Front. Plant Sci. 8, 1492. doi: 10.3389/fpls.2017.01492

Hasanuzzaman, M., Bhuyan, M. H. M., Raza, A., Hawrylak-Nowak, B., Matraszek-Gawron, R., Nahar, K., et al. (2020). Selenium toxicity in plants and environment: biogeochemistry and remediation possibilities. Plan. Theory 9:1711. doi: 10.3390/plants9121711

Hasgül, E., Malkoç, S., Güven, A., Dede, A., and Güven, K. (2019). Biosorption of cadmium and copper by aspergillus spp. isolated from industrial ceramic waste sludge. Biodivers. Conserv. 12, 44-56. doi: 10.5505/biodicon.2019. 42714

Hassan, A., Pariatamby, A., Ahmed, A., Auta, H. S., and Hamid, F. S. (2019). Enhanced bioremediation of heavy metal contaminated landfill soil using filamentous fungi consortia: a demonstration of bioaugmentation potential. Water Air Soil Pollut. 230, 1-20. doi: 10.1007/s11270-019-4227-5

Hassan, A., Pariatamby, A., Ossai, I. C., and Hamid, F. S. (2020b). Bioaugmentation assisted mycoremediation of heavy metal and/metalloid landfill contaminated soil using consortia of filamentous fungi. Biochem. Eng. J. 157:107550. doi: 10.1016/j.bej.2020.107550

Hassan, A., Periathamby, A., Ahmed, A., Innocent, O., and Hamid, F. S. (2020a). Effective bioremediation of heavy metal-contaminated landfill soil through bioaugmentation using consortia of fungi. J. Soils Sediments 20, 66-80. doi: 10.1007/s11368-019-02394-4

Hazen, T. C. (2010). "In situ: groundwater bioremediation," in Handbook of Hydrocarbon and Lipid Microbiology. ed. K. N. Timmis (Berlin: Springer), 2583-2594.

Hellekson, D. (1999). Bioventing principles, applications and potential. Restor. Principles Appl. Potential 5, 1-9.

Hrynkiewicz, K., Dabrowska, G., Baum, C., Niedojadlo, K., and Leinweber, P. (2012). Interactive and single effects of ectomycorrhiza formation and Bacillus cereus on metallothionein MT1 expression and phytoextraction of $\mathrm{Cd}$ and Zn by Willows. Water Air Soil Pollut. 223, 957-968. doi: 10.1007/ s11270-011-0915-5 
Huang, D., Qin, X., Peng, Z., Liu, Y., Gong, X., Zeng, G., et al. (2018). Nanoscale zero-valent iron assisted phytoremediation of $\mathrm{Pb}$ in sediment: impacts on metal accumulation and antioxidative system of Lolium perenne. Ecotoxicol. Environ. Saf. 153, 229-237. doi: 10.1016/j.ecoenv.2018.01.060

Huang, Y., Xi, Y., Gan, L., Johnson, D., Wu, Y., Ren, D., et al. (2019). Effects of lead and cadmium on photosynthesis in Amaranthus spinosus and assessment of phytoremediation potential. Int. J. Phytoremediation 21, 1041-1049. doi: 10.1080/15226514.2019.1594686

Hussain, F., Hadi, F., and Akbar, F. (2019). Magnesium oxide nanoparticles and thidiazuron enhance lead phytoaccumulation and antioxidative response in Raphanus sativus L. Environ. Sci. Pollut. Res. 26, 30333-30347. doi: 10.1007/s11356-019-06206-7

Ibrahim, U. B., Yahaya, S., Yusuf, I., and Kawo, A. H. (2021). Optimization and simulation of process parameters in biosorption of heavy metals by Alcaligenes Faecalis strain UBI (MT107249) isolated from soil of local mining area in North-West Nigeria. Soil Sediment Contam. 1-18. doi: 10.1080/15320383.2021.1963211

Ipeaiyeda, A. R., Adenipekun, C. O., and Oluwole, O. (2020). Bioremediation potential of Ganoderma lucidum (Curt: Fr) P. Karsten to remove toxic metals from abandoned battery slag dumpsite soil and immobilisation of metal absorbed fungi in bricks. Cogent. Environ. Sci. 6:1847400. doi: 10.1080/23311843.2020.1847400

Iram, S., Shabbir, R., Zafar, H., and Javaid, M. (2015). Biosorption and bioaccumulation of copper and lead by heavy metal-resistant fungal isolates. Arab. J. Sci. Eng. 40, 1867-1873. doi: 10.1007/s13369-015-1702-1

Irshad, S., Xie, Z., Wang, J., Nawaz, A., Luo, Y., Wang, Y., et al. (2020). Indigenous strain Bacillus XZM assisted phytoremediation and detoxification of arsenic in Vallisneria denseserrulata. J. Hazard. Mater. 381:120903. doi: 10.1016/j.jhazmat.2019.120903

Issazadeh, K., Jahanpour, N., Pourghorbanali, F., Raeisi, G., and Faekhondeh, J. (2013). Heavy metals resistance by bacterial strains. Ann. Biol. Res. 4, 60-63.

Jampasri, K., Pokethitiyook, P., Poolpak, T., Kruatrachue, M., Ounjai, P., and Kumsopa, A. (2020). Bacteria-assisted phytoremediation of fuel oil and lead co-contaminated soil in the salt-stressed condition by chromolaena odorata and Micrococcus luteus. Int. J. Phytoremediation 22, 322-333. doi: 10.1080/15226514.2019.1663482

Jan, A. T., Azam, M., Ali, A., and Haq, Q. M. R. (2014). Prospects for exploiting bacteria for bioremediation of metal pollution. Crit. Rev. Environ. Sci. Technol. 44, 519-560. doi: 10.1080/10643389.2012.728811

Janoušková, M., Pavlíková, D., Macek, T., and Vosátka, M. (2005). Arbuscular mycorrhiza decreases cadmium phytoextraction by transgenic tobacco with inserted metallothionein. Plant Soil 272, 29-40. doi: 10.1007/s11104-0043847-7

Javanbakht, V., Alavi, S. A., and Zilouei, H. (2014). Mechanisms of heavy metal removal using microorganisms as biosorbent. Water Sci. Technol. 69, 1775-1787. doi: 10.2166/wst.2013.718

Jeyasundar, P. G. S. A., Ali, A., Azeem, M., Li, Y., Guo, D., Sikdar, A., et al. (2021). Green remediation of toxic metals contaminated mining soil using bacterial consortium and Brassica juncea. Environ. Pollut. 277:116789. doi: 10.1016/j.envpol.2021.116789

Jin, Z., Deng, S., Wen, Y., Jin, Y., Pan, L., Zhang, Y., et al. (2019). Application of Simplicillium chinense for $\mathrm{Cd}$ and $\mathrm{Pb}$ biosorption and enhancing heavy metal phytoremediation of soils. Sci. Total Environ. 697:134148. doi: 10.1016/j. scitotenv.2019.134148

Jin, Y., Luan, Y., Ning, Y., and Wang, L. (2018). Effects and mechanisms of microbial remediation of heavy metals in soil: a critical review. Appl. Sci. 8:1336. doi: 10.3390/app8081336

Junior, R. B. R., Meira, H. M., Almeida, D. G., Rufino, R. D., Luna, J. M., Santos, V. A., et al. (2019). Application of a low-cost biosurfactant in heavy metal remediation processes. Biodegradation 30, 215-233. doi: 10.1007/ s10532-018-9833-1

Kang, C. H., Kwon, Y. J., and So, J. S. (2016). Bioremediation of heavy metals by using bacterial mixtures. Ecol. Eng. 89, 64-69. doi: 10.1016/j.ecoleng.2016.01.023

Kanmani, P., Aravind, J., and Preston, D. (2012). Remediation of chromium contaminants using bacteria. Int. J. Environ. Sci. Technol. 9, 183-193. doi: 10.1007/s13762-011-0013-7

Kernaghan, C. (2005). Mycorrhizal diversity: cause and effect? Pedobiologia 49, 511-520. doi: 10.1016/j.pedobi.2005.05.007
Khan, N., and Bano, A. (2016). Modulation of phytoremediation and plant growth by the treatment with PGPR, Ag nanoparticle and untreated municipal wastewater. Int. J. Phytoremediation 18, 1258-1269. doi: 10.1080/15226514.2016.1203287

Khan, N., and Bano, A. (2018). Effects of exogenously applied salicylic acid and putrescine alone and in combination with rhizobacteria on the phytoremediation of heavy metals and chickpea growth in sandy soil. Int. J. Phytoremediation 20, 405-414. doi: 10.1080/15226514.2017. 1381940

Khan, N., Zandi, P., Ali, S., Mehmood, A., Adnan Shahid, M., and Yang, J. (2018). Impact of salicylic acid and PGPR on the drought tolerance and phytoremediation potential of Helianthus annus. Front. Microbiol. 9:2507. doi: $10.3389 /$ fmicb.2018.02507

Khodaverdiloo, H., Han, F. X., Hamzenejad Taghlidabad, R., Karimi, A., Moradi, N., and Kazery, J. A. (2020). Potentially toxic element contamination of arid and semi-arid soils and its phytoremediation. Arid Land Res. Manag. 34, 361-391. doi: 10.1080/15324982.2020.1746707

Kodituwakku, K. A. R. K., and Yatawara, M. (2020). Phytoremediation of industrial sewage sludge with Eichhornia crassipes, Salvinia molesta and Pistia stratiotes in batch fed free water fow constructed wetlands. Bull. Environ. Contam. Toxicol. 104, 627-633. doi: 10.1007/s00128-020-02805-0

Krämer, U., Talke, I. N., and Hanikenne, M. (2007). Transition metal transport. FEBS Lett. 581, 2263-2272. doi: 10.1016/j.febslet.2007.04.010

Kullu, B., Patra, D. K., Acharya, S., Pradhan, C., and Patra, H. K. (2020). AM fungi mediated bioaccumulation of hexavalent chromium in Brachiaria mutica-a mycorrhizal phytoremediation approach. Chemosphere 258:127337. doi: 10.1016/j.chemosphere.2020.127337

Kumar, N. (2019). "Natural and artificial soil amendments for the efficient phytoremediation of contaminated soil," in Phyto and Rhizo Remediation (Singapore: Springer), 1-32.

Kumar, R., Acharya, C., and Joshi, S. R. (2011). Isolation and analyses of uranium tolerant Serratia marcescens strains and their utilization for aerobic uranium U(VI) bioadsorption. J. Microbiol. 49, 568-574. doi: 10.1007/ s12275-011-0366-0

Kumar, A., Bisht, B. S., Joshi, V. D., and Dhewa, T. (2011b). Review on bioremediation of polluted environment: a management tool. Int. J. Environ. Sci. 1, 1079-1093.

Kumar, A., Maleva, M., Bruno, L. B., and Rajkumar, M. (2021b). Synergistic effect of ACC deaminase producing Pseudomonas sp. TR15a and siderophore producing Bacillus aerophilus TR15c for enhanced growth and copper accumulation in Helianthus annuus L. Chemosphere 276:130038. doi: 10.1016/j. chemosphere.2021.130038

Kumar, A., Voropaeva, O., Maleva, M., Panikovskaya, K., Borisova, G., Rajkumar, M., et al. (2021a). Bioaugmentation with copper tolerant endophyte Pseudomonas lurida strain EOO26 for improved plant growth and copper phytoremediation by Helianthus annuus. Chemosphere 266:128983. doi: 10.1016/j.chemosphere.2020.128983

Lee, Y. C., and Chang, S. P. (2011). The biosorption of heavy metals from aqueous solution by spirogyra and Cladophora filamentous macroalgae. Bioresour. Technol. 102, 5297-5304. doi: 10.1016/j.biortech.2010.12.103

Lee, K. Y., Ho, L. Y., Tan, K. H., Tham, Y. Y., Ling, S. P., Qureshi, A. M., et al. (2017). Environmental and occupational health impact of bauxite mining in Malaysia: a review. IIUM Med. J. Malaysia 16, 137-150. doi: 10.31436/imjm.v16i2.346

Leong, Y. K., and Chang, J. S. (2020). Bioremediation of heavy metals using microalgae: recent advances and mechanisms. Bioresour. Technol. 303:122886. doi: 10.1016/j.biortech.2020.122886

Lewis, S., Donkin, M. E., and Depledge, M. H. (2001). Hsp70 expression in Enteromorpha intestinalis (Chlorophyta) exposed to environmental stressors. Aquat. Toxico. 51, 277-291. doi: 10.1016/S0166-445X(00)00119-3

Li, J., Chang, Y., Al-Huqail, A. A., Ding, Z., Al-Harbi, M. S., Ali, E. F., et al. (2021). Effect of manure and compost on the phytostabilization potential of heavy metals by the halophytic plant wavy-leaved saltbush. Plan. Theory 10:2176. doi: 10.3390/plants10102176

Li, X., Li, D., Yan, Z., and Ao, Y. (2018). Biosorption and bioaccumulation characteristics of cadmium by plant growth-promoting rhizobacteria. RSC Adv. 8, 30902-30911. doi: 10.1039/C8RA06270F

Li, Y., Lin, J., Huang, Y., Yao, Y., Wang, X., Liu, C., et al. (2020). Bioaugmentationassisted phytoremediation of manganese and cadmium co-contaminated soil 
by Polygonaceae plants (Polygonum hydropiper L. and Polygonum lapathifolium L.) and Enterobacter sp. FM-1. Plant Soil 448, 439-453. doi: 10.1007/ s11104-020-04447-x

Li, R., Wu, H., Ding, J., Li, N., Fu, W., Gan, L., et al. (2020a). Transgenic merA and merB expression reduces mercury contamination in vegetables and grains grown in mercury-contaminated soil. Plant Cell Rep. 39, 1369-1380. doi: $10.1007 / \mathrm{s} 00299-020-02570-8$

Li, X., Xiao, J., Salam, M. M. A., Ma, C., and Chen, G. (2021a). Impacts of bamboo biochar on the phytoremediation potential of Salix psammophila grown in multi-metals contaminated soil. Int. J. Phytoremediation 23, 387-399. doi: $10.1080 / 15226514.2020 .1816893$

Lim, M. W., Von Lau, E., and Poh, P. E. (2016). A comprehensive guide of remediation technologies for oil contaminated soil-present works and future directions. Mar. Pollut. Bull. 109, 14-45. doi: 10.1016/j.marpolbul.2016.04.023

Lin, H., Liu, C., Li, B., and Dong, Y. (2021). Trifolium repens L. regulated phytoremediation of heavy metal contaminated soil by promoting soil enzyme activities and beneficial rhizosphere associated microorganisms. J. Hazard. Mater. 402:123829. doi: 10.1016/j.jhazmat.2020.123829

Liu, D., An, Z., Mao, Z., Ma, L., and Lu, Z. (2015a). Enhanced heavy metal tolerance and accumulation by transgenic sugar beets expressing Streptococcus thermophilus stgcs-gs in the presence of $\mathrm{Cd}, \mathrm{Zn}$ and $\mathrm{Cu}$ alone or in combination. PLoS One 10:e0128824. doi: 10.1371/journal.pone.0128824

Liu, C., Lin, H., Li, B., Dong, Y., and Menzembere, E. R. G. Y. (2021b). Endophyte pseudomonas putida enhanced Trifolium repens L. growth and heavy metal uptake: A promising in-situ non-soil cover phytoremediation method of nonferrous metallic tailing. Chemosphere 272:129816. doi: 10.1016/j. chemosphere.2021.129816

Liu, S., Liu, H., Chen, R., Ma, Y., Yang, B., Chen, Z., et al. (2021a). Role of two plant growth-promoting bacteria in remediating cadmium-contaminated soil combined with Miscanthus floridulus (Lab.). Plan. Theory 10:912. doi: 10.3390/plants10050912

Liu, B., Wang, S., Wang, J., Zhang, X., Shen, Z., Shi, L., et al. (2020). The great potential for phytoremediation of abandoned tailings pond using ectomycorrhizal Pinus sylvestris. Sci. Total Environ. 719:137475. doi: 10.1016/j.scitotenv.2020.137475

Liu, H., Yuan, M., Tan, S., Yang, X., Lan, Z., Jiang, Q., et al. (2015b). Enhancement of arbuscular mycorrhizal fungus (Glomus versiforme) on the growth and $\mathrm{Cd}$ uptake by Cd-hyperaccumulator Solanum nigrum. Appl. Soil Ecol. 89, 44-49. doi: 10.1016/j.apsoil.2015.01.006

Lívia, D. C., Mario, H. B., and Benedito, C. (2015). Potential application of modified Saccharomyces cerevisiae for removing lead and cadmium. J. Bioremed. Biodegr. 6, 1-5. doi: 10.4172/2155-6199.1000313

Lombi, E., and Hamon, R. E. (2005). Remediation of polluted soils. Encycl. Soils Environ., 379-385. doi: 10.1016/B0-12-348530-4/00087-4

Lu, M., Jiao, S., Gao, E., Song, X., Li, Z., Hao, X., et al. (2017). Transcriptome response to heavy metals in Sinorhizobium meliloti CCNWSX0020 reveals new metal resistance determinants that also promote bioremediation by Medicago lupulina in metal-contaminated soil. ppl. Environ. Microbiol. 83:e01244-17. doi: 10.1128/AEM.01244-17

Ma, Y., Prasad, M., Rajkumar, M., and Freitas, H. (2011). Plant growth promoting rhizobacteria and endophytes accelerate phytoremediation of metalliferous soils. Biotechnol. Adv. 29, 248-258. doi: 10.1016/j.biotechadv.2010.12.001

Ma, Y., Rajkumar, M., Oliveira, R. S., Zhang, C., and Freitas, H. (2019). Potential of plant beneficial bacteria and arbuscular mycorrhizal fungi in phytoremediation of metal-contaminated saline soils. J. Hazard. Mater. 379:120813. doi: 10.1016/j.jhazmat.2019.120813

Ma, Y., Rajkumar, M., Zhang, C., and Freitas, H. (2016). Inoculation of Brassica oxyrrhina with plant growth promoting bacteria for the improvement of heavy metal phytoremediation under drought conditions. J. Hazard. Mater. 320, 36-44. doi: 10.1016/j.jhazmat.2016.08.009

Mandal, A., Thakur, J., Sahu, A., Bhattacharjya, S., Manna, M., and Patra, A. K. (2016). "Plant-microbe interaction for the removal of heavy metal from contaminated site," in Plant-Microbe Interaction: An Approach to Sustainable Agriculture (Singapore: Springer), 227-247.

Mane, P. C., and Bhosle, A. B. (2012). Bioremoval of some metals by living Algae Spirogyra sp. and Spirullina sp. from aqueous solution. Int. J. Environ. Res. 6, 571-576.

Mangunwardoyo, W., Sudjarwo, T., and Patria, M. P. (2013). Bioremediation of effluent wastewater treatment plant Bojongsoang Bandung Indonesia using consortium aquatic plants and animals. Int. J. Res. Rev. Appl. Sci. 14, 150-160.
Mani, D., and Kumar, C. (2014). Biotechnological advances in bioremediation of heavy metals contaminated ecosystems: an overview with special reference to phytoremediation. Int. J. Environ. Sci. Technol. 11, 843-872. doi: 10.1007/ s13762-013-0299-8

Manoj, S. R., Karthik, C., Kadirvelu, K., Arulselvi, P. I., Shanmugasundaram, T., Bruno, B., et al. (2020). Understanding the molecular mechanisms for the enhanced phytoremediation of heavy metals through plant growth promoting rhizobacteria: a review. J. Environ. Manag. 254:109779. doi: 10.1016/j. jenvman.2019.109779

Mariconi, J. R., Moreira, H. P., de Andrade Silva, L. E., Melo, V. S. R., dos Santos Senhuk, A. P. M., Ferreira, D. C., et al. (2020). The bioremediation potential of filamentous fungi in soil contaminated with lead. Ciencia $e$ Natura. 42:e37. doi: 10.5902/2179460X41262

Mascher, R., Lippmann, B., Holzinger, S., and Bergmann, H. (2006). Arsenate toxicity: effects on oxidative stress response molecules and enzymes in red clover plants. Plant Sci. 63, 961-969. doi: 10.1016/S0168-9452(02)00245-5

Mataruga, Z., Jarić, S., Marković, M., Pavlović, M., Pavlović, D., Jakovljević, K., et al. (2020). Evaluation of Salix alba, Juglans regia and Populus nigra as biomonitors of PTEs in the riparian soils of the Sava River. Environ. Monit. Assess. 192:131. doi: 10.1007/s10661-020-8085-9

Meagher, R. B. (2000). Phytoremediation of toxic elemental and organic pollutants. Curr. Opin. Plant Biol. 3, 153-162. doi: 10.1016/S1369-5266(99)00054-0

Megharaj, M., Ramakrishnan, B., Venkateswarlu, K., Sethunathan, N., and Naidu, R. (2011). Bioremediation approaches for organic pollutants: a critical perspective. Environ. Int. 37, 1362-1375. doi: 10.1016/j.envint. 2011.06.003

Meier, S., Borie, F., Bolan, N., and Cornejo, P. (2012). Phytoremediation of metal-polluted soils by arbuscular mycorrhizal fungi. Crit. Rev. Environ. Sci. Technol. 42, 741-775. doi: 10.1080/10643389.2010.528518

Mesa-Marín, J., Pérez-Romero, J. A., Redondo-Gómez, S., Pajuelo, E., Rodríguez-Llorente, I. D., and Mateos-Naranjo, E. (2020). Impact of plant growth promoting bacteria on Salicornia ramosissima ecophysiology and heavy metal phytoremediation capacity in estuarine soils. Front. Microbiol. 11:2148. doi: $10.3389 /$ fmicb. 2020.553018

Mohammadian, E., Ahari, A. B., Arzanlou, M., Oustan, S., and Khazaei, S. H. (2017). Tolerance to heavy metals in filamentous fungi isolated from contaminated mining soils in the Zanjan Province, Iran. Chemosphere 185, 290-296. doi: 10.1016/j.chemosphere.2017.07.022

Mohapatra, R. K., Parhi, P. K., Pandey, S., Bindhani, B. K., Thatoi, H., and Panda, C. R. (2019). Active and passive biosorption of $\mathrm{Pb}$ (II) using live and dead biomass of marine bacterium Bacillus xiamenensis PbRPSD202: kinetics and isotherm studies. J. Environ. Manag. 247, 121-134. doi: 10.1016/j. jenvman.2019.06.073

Muszynska, E., and Hanus-Fajerska, E. (2015). Why are heavy metal hyperaccumulating plants so amazing? BioTechnol. J. Biotechnol. Comput. Biol. Bionanotechnol. 96, 265-271. doi: 10.5114/bta.2015.57730

Nawrot, T., Plusquin, M., Hogervorst, J., Roels, H. A., Celis, H., Thijs, L., et al. (2006). Environmental exposure to cadmium and risk of cancer: a prospective population-based study. Lancet Oncol. 7, 119-126. doi: 10.1016/ S1470-2045(06)70545-9

Ndeddy Aka, R. J., and Babalola, O. O. (2016). Effect of bacterial inoculation of strains of pseudomonas aeruginosa, alcaligenes feacalis and Bacillus subtilis on germination, growth and heavy metal (Cd, $\mathrm{Cr}$, and $\mathrm{Ni}$ ) uptake of Brassica juncea. Int. J. Phytoremediation 18, 200-209. doi: 10.1080/15226514.2015.1073671

Nedjimi, B. (2021). Phytoremediation: a sustainable environmental technology for heavy metals decontamination. SN Appl. Sci. 3, 1-19. doi: 10.1007/ s42452-021-04301-4

Nester, E. W., Anderson, D. G., Roberts, C. E., Pearsall, N. N., and Nester, M. T. (2001). "Dynamics of prokaryotic growth," in Microbiology: A Human Perspective. 3rd Edn. (New York: McGraw-Hill), 87-108.

Njoku, K. L., Akinyede, O. R., and Obidi, O. F. (2020). Microbial remediation of heavy metals contaminated media by Bacillus megaterium and Rhizopus stolonifer. Scientific African. 10:e00545. doi: 10.1016/j.sciaf.2020.e00545

Noormohamadi, H. R., Fat'hi, M. R., Ghaedi, M., and Ghezelbash, G. R. (2019). Potentiality of white-rot fungi in biosorption of nickel and cadmium: Modeling optimization and kinetics study. Chemosphere 216, 124-130. doi: 10.1016/j. chemosphere.2018.10.113

Nugroho, A. P., Butar, E. S. B., Priantoro, E. A., Sriwuryandari, L., Pratiwi, Z. B., and Sembiring, T. (2021). Phytoremediation of electroplating wastewater by 
vetiver grass (Chrysopogon zizanoides L.). Sci. Rep. 11, 1-8. doi: 10.1038/ s41598-021-93923-0

Nurfitriani, S., Arisoesilaningsih, E., Nuraini, Y., and Handayanto, E. (2020). Bioaccumulation of mercury by bacteria isolated from small scale gold mining tailings in Lombok, Indonesia. J. Ecol. Eng. 21, 127-136. doi: $10.12911 / 22998993 / 123247$

Odoh, R., Agbaji, E. B., and Kagbu, J. A. (2019). Assessment of trace metals pollution in auto-mechanic workshop in some selected local government area of Benue state, Nigeria. Int. J. Chem. 3, 78-88. doi: 10.5539/ijc.v3n4p78

Ojuederie, O. B., and Babalola, O. O. (2017). Microbial and plant-assisted bioremediation of heavy metal polluted environments: a review. Int. J. Env. Res. Public Health. 14:1504. doi: 10.3390/ijerph14121504

Oka, T., Sameshima, Y., Koga, T., Kim, H., Goto, M., and Furukawa, K. (2005). Protein Omannosyltransferase a of Aspergillus awamori is involved in O-mannosylation of glucoamylase I. Microbiology-Sgm. 151, 3657-3667. doi: 10.1099/mic.0.28088-0

Ong, G. H., Ho, X. H., Shamkeeva, S., Manasha Savithri Fernando, A. S., and Wong, L. S. (2017). Biosorption study of potential fungi for copper remediation from peninsular Malaysia. Remediat. J. 27, 59-63. doi: 10.1002/ rem. 21531

Oves, M., Khan, M. S., and Qari, H. A. (2017). Ensifer adhaerens for heavy metal bioaccumulation, biosorption, and phosphate solubilization under metal stress condition. Taiwan Inst. Chem. Eng. 80, 540-552. doi: 10.1016/j.jtice.2017.08.026

Oziegbe, O., Oluduro, A. O., Oziegbe, E. J., Ahuekwe, E. F., and Olorunsola, S. J. (2021). Assessment of heavy metal bioremediation potential of bacterial isolates from landfill soils. Saudi J. Biol. Sci. 28, 3948-3956. doi: 10.1016/j. sjbs.2021.03.072

Padmavathiamma, P. K., and Li, L. Y. (2007). Phytoremediation technology: hyper-accumulation metals in plants. Water Air Soil Pollut. 184, 105-126. doi: 10.1007/s11270-007-9401-5

Palanivel, T. M., Pracejus, B., and Victor, R. (2020). Phytoremediation potential of castor (Ricinus communis L.) in the soils of the abandoned copper mine in Northern Oman: implications for arid regions. Environ. Sci. Pollut. Res. 27, 17359-17369. doi: 10.1007/s11356-020-08319-w

Papadopoulos, N., and Zalidis, G. (2019). The use of Typha Latifolia L. in constructed wetland microcosms for the remediation of herbicide Terbuthylazine. Environ. Process. 6, 985-1003. doi: 10.1007/s40710-019-00 398-3

Park, J. H., and Chon, H. T. (2016). Characterization of cadmium biosorption by Exiguobacterium sp. isolated from farmland soil near $\mathrm{Cu}-\mathrm{Pb}-\mathrm{Zn}$ mine. Environ. Sci. Pollut. Res. 23, 11814-11822. doi: 10.1007/s11356-016-6335-8

Petavratzi, E., Kingman, S., and Lowndes, I. (2005). Particulates from mining operations: A review of sources, effects and regulations. Miner. Eng. 18, 1183-1199. doi: 10.1016/j.mineng.2005.06.017

Phulia, V., Jamwal, A., Saxena, N., Chadha, N. K., Muralidhar, A. P., and Prusty, A. K. (2013). "Technologies in aquatic bioremediation," in Freshwater ecosystem and xenobiotics. New Delhi: Discovery Publishing House PVT. Ltd., 65-91.

Pietro-Souza, W., de Campos Pereira, F., Mello, I. S., Stachack, F. F. F., Terezo, A. J., da Cunha, C. N., et al. (2020). Mercury resistance and bioremediation mediated by endophytic fungi. Chemosphere 240:124874. doi: 10.1016/j. chemosphere.2019.124874

Pourret, O., Lange, B., Bonhoure, J., Colinet, G., Decrée, S., Mahy, G., et al. (2016). Assessment of soil metal distribution and environmental impact of mining in Katanga (Democratic Republic of Congo). J. Appl. Geochem. 64, 43-55. doi: 10.1016/j.apgeochem.2015.07.012

Pranaw, K., Pidlisnyuk, V., Trögl, J., and Malinská, H. (2020). Bioprospecting of a novel plant growth-promoting bacterium Bacillus altitudinis KP-14 for enhancing Miscanthus giganteus growth in metals contaminated soil. Biology 9:305. doi: 10.3390/biology9090305

Qi, C., Huang, J., Wang, B., Deng, S., Wang, Y., and Yu, G. (2018). Contaminants of emerging concern in landfill leachate in China: a review. Emerg. Contam. 4, 1-10. doi: 10.1016/j.emcon.2018.06.001

Rahman, A., Nahar, N., Nawani, N. N., Jass, J., Hossain, K., Saud, Z. A., et al. (2015). Bioremediation of hexavalent chromium (VI) by a soil-borne bacterium, Enterobacter cloacae B2-DHA. J. Environ. Sci. Health A 50, 1136-1147. doi: 10.1080/10934529.2015.1047670

Raklami, A., Oufdou, K., Tahiri, A. I., Mateos-Naranjo, E., Navarro-Torre, S., Rodríguez-Llorente, I. D., et al. (2019). Safe cultivation of Medicago sativa in metal-polluted soils from semi-arid regions assisted by heat-and metalloresistant PGPR. Microorganisms 7:212. doi: 10.3390/microorganisms7070212

Ramos, J. L., Gonzalez-Perez, M. M., Caballero, A., and Van Dillewijn, P. (2005). Bioremediation of polynitrated aromatic compounds: plants and microbes put up a fight. Curr. Opin. Biotechnol. 16, 275-281. doi: 10.1016/j. copbio. 2005.03 .010

Ramos, J. L., Marques, S., Dillewijn, P. V., Espinosa-Urgel, M., Segura, A., Duque, E., et al. (2011). Laboratory research aimed at closing the gaps in microbial bioremediation. Trends Biotechnol. 29, 641-647. doi: 10.1016/j. tibtech.2011.06.007

Rascio, N., and Navari-Izzo, F. (2011). Heavy metal hyper-accumulating plants: how and why do they do it? And what makes them so interesting? Plant Sci. 180, 169-181. doi: 10.1016/j.plantsci.2010.08.016

Rayu, S., Karpouzas, D. G., and Singh, B. K. (2012). Emerging technologies in bioremediation: constraints and opportunities. Biodegradation 23, 917-926. doi: 10.1007/s10532-012-9576-3

Raza, A., Habib, M., Kakavand, S. N., Zahid, Z., Zahra, N., Sharif, R., et al. (2020). Phytoremediation of cadmium: physiological, biochemical, and molecular mechanisms. Biology 9:177. doi: 10.3390/biology9070177

Razmi, B., Ghasemi-Fasaei, R., Ronaghi, A., and Mostowfizadeh-Ghalamfarsa, R. (2021). Investigation of factors affecting phytoremediation of multi-elements polluted calcareous soil using Taguchi optimization. Ecotoxicol. Environ. Saf. 207:111315. doi: 10.1016/j.ecoenv.2020.111315

Reinhardt, D. (2007). Programming good relation development of the arbuscular mycorrhizal symbiosis. Plant Biol. 10, 98-105. doi: 10.1016/j.pbi.2006.11.001

Rizvi, A., Ahmed, B., Zaidi, A., and Khan, M. S. (2020). Biosorption of heavy metals by dry biomass of metal tolerant bacterial biosorbents: an efficient metal clean-up strategy. Environ. Monit. Assess. 192, 1-21. doi: 10.1007/ s10661-020-08758-5

Rubin, J. A., and Görres, J. H. (2021). Potential for mycorrhizae-assisted phytoremediation of phosphorus for improved water quality. Int. J. Env. Res. Public Health. 18:7. doi: 10.3390/ijerph18010007

Saadani, O., Jebara, S. H., Fatnassi, I. C., Chiboub, M., Mannai, K., Zarrad, I., et al. (2019). Effect of Vicia faba L. var. minor and Sulla coronaria (L.) Medik associated with plant growth-promoting bacteria on lettuce cropping system and heavy metal phytoremediation under field conditions. Environ. Sci. Pollut. Res. 26, 8125-8135. doi: 10.1007/s11356-019-04302-2

Saba, Rehman, Y., Ahmed, M., and Sabri, A. N. (2019). Potential role of bacterial extracellular polymeric substances as biosorbent material for arsenic bioremediation. Biorem. J. 23, 72-81. doi: 10.1080/10889868.2019.1602107

Sachan, P., and Lal, N. (2017). An overview of nickel $\left(\mathrm{Ni}^{2+}\right)$ essentiality, toxicity and tolerance strategies in plants. Asian J. Biol. 2, 1-15. doi: 10.9734/ AJOB/2017/33931

Saeed-ur-Rahman, M. K., Kayani, S. I., and Tang, K. (2020). The ameliorative effects of exogenous inoculation of Piriformospora indica on molecular, biochemical and physiological parameters of Artemisia annua L. under arsenic stress condition. Ecotoxicol. Environ. Saf. 206:111202. doi: 10.1016/j. ecoenv.2020.111202

Saha, L., and Bauddh, K. (2020). "Characteristics of mining spoiled and oil drilling sites and adverse impacts of these activities on the environment and human health," in Phytorestoration of Abandoned Mining and Oil Drilling Sites (Amsterdam: Elsevier), 87-101.

Saleem, M. H., Ali, S., Rehman, M., Hasanuzzaman, M., Rizwan, M., Irshad, S., et al. (2020). Jute: A potential candidate for phytoremediation of metals-A review. Plan. Theory 9:258. doi: 10.3390/plants9020258

Sampaio, C. J. S., de Souza, J. R. B., Damião, A. O., Bahiense, T. C., and Roque, M. R. A. (2019). Biodegradation of polycyclic aromatic hydrocarbons (PAHs) in a diesel oil-contaminated mangrove by plant growth-promoting rhizobacteria. 3 Biotech 9:155. doi: 10.1007/s13205-019-1686-8

Sangsuwan, P., and Prapagdee, B. (2021). Cadmium phytoremediation performance of two species of Chlorophytum and enhancing their potentials by cadmiumresistant bacteria. Environ. Technol. Innov. 21:101311. doi: 10.1016/j. eti.2020.101311

Sarwar, N., Imran, M., Shaheen, M. R., Ishaque, W., Kamran, M. A., Matloob, A., et al. (2017). Phytoremediation strategies for soils contaminated with heavy metals: modifications and future perspectives. Chemosphere 171, 710-721. doi: 10.1016/j.chemosphere.2016.12.116

Sedlakova-Kadukova, J., Kopcakova, A., Gresakova, L., Godany, A., and Pristas, P. (2019). Bioaccumulation and biosorption of zinc by a novel Streptomyces 
K11 strain isolated from highly alkaline aluminium brown mud disposal site. Ecotoxicol. Environ. Saf. 167, 204-211. doi: 10.1016/j.ecoenv.2018.09.123

Seviour, R. J., Mino, T., and Onuki, M. (2003). The microbiology of biological phosphorus removal in activated sludge systems. FEMS Microbiol. Rev. 27, 99-127. doi: 10.1016/S0168-6445(03)00021-4

Shah, K., and Nongkynrih, J. M. (2007). Metal hyperaccumulation and bioremediation. Biol. Plant. 51, 618-634. doi: 10.1007/s10535-007-0134-5

Shaibur, M. R., Kitajima, N., Huq, S. I., and Kawai, S. (2009). Arsenic-iron interaction: effect of additional iron on arsenic-induced chlorosis in barley grown in water culture. Soil Sci. Plant Nutr. 55, 739-746. doi: 10.1111/j.1747-0765.2009.00414.x

Sharma, J. (2019). Advantages and limitations of in situ methods of bioremediation. Recent Adv. Biol. Med. 5:1. doi: 10.18639/RABM.2019.955923

Sharma, R., Jasrotia, T., Sharma, S., Sharma, M., Kumar, R., Vats, R., et al. (2021). Sustainable removal of $\mathrm{Ni}$ (II) from waste water by freshly isolated fungal strains. Chemosphere 282:130871. doi: 10.1016/j. chemosphere.2021.130871

Sharma, B., and Shukla, P. (2021a). A comparative analysis of heavy metal bioaccumulation and functional gene annotation towards multiple metal resistant potential by Ochrobactrum intermedium BPS-20 and Ochrobactrum ciceri BPS-26. Bioresour. Technol. 320:124330. doi: 10.1016/j.biortech.2020. 124330

Sharma, B., and Shukla, P. (2021b). Lead bioaccumulation mediated by Bacillus cereus BPS-9 from an industrial waste contaminated site encoding heavy metal resistant genes and their transporters. J. Hazard. Mater. 401:123285. doi: 10.1016/j.jhazmat.2020.123285

Sheoran, V., Sheoran, A. S., and Poonia, P. (2009). Phytomining: A review. Miner. Eng. 22, 1007-1019. doi: 10.1016/j.mineng.2009.04.001

Shukla, A. K., Singh, Y. K., and Pandey, V. K. (2020). "Phytoremediation of pollutants from soil," in Plant Responses to Soil Pollution (Singapore: Springer), $155-161$.

Siezen, R. J., and Galardini, M. (2008). Genomics of biological wastewater treatment. Microb. Biotechnol. 1, 333-340. doi: 10.1111/j.1751-7915.2008.00059.x

Singh, P. K. (2012). Role of glomalin related soil protein produced by arbuscular mycorrhizal fungi: a review. Agric. Sci. Res. J. 2, 119-125.

Singh, J., and Lee, B. K. (2016). Influence of nano- $\mathrm{TiO}_{2}$ particles on the bioaccumulation of $\mathrm{cd}$ in soybean plants (Glycine max): a possible mechanism for the removal of $\mathrm{cd}$ from the contaminated soil. J. Environ. Manag. 170, 88-96. doi: 10.1016/j.jenvman.2016.01.015

Singh, S., Saha, L., Kumar, M., and Bauddh, K. (2021). "Phytoremediation potential of invasive species growing in mining dumpsite," in Phytorestoration of Abandoned Mining and Oil Drilling Sites (Amsterdam: Elsevier), 287-305.

Smets, B. F., and Pritchard, P. H. (2003). Elucidating the microbial component of natural attenuation. Curr. Opin. Biotechnol. 14, 283-288. doi: 10.1016/ S0958-1669(03)00062-4

Sobrinho, H. B., Luna, J. M., Rufino, R. D., Porto, A. L. F., and Sarubbo, L. A. (2013). Biosurfactants: classification, properties and environmental applications. Rec. Dev. Biotechnol. 11, 1-29.

Souri, Z., Karimi, N., Sarmadi, M., and Rostami, E. (2017). Salicylic acid nanoparticles (SANPs) improve growth and phytoremediation efficiency of Isatis cappadocica Desv., under As stress. IET Nanobiotechnol. 11, 650-655. doi: 10.1049/iet-nbt.2016.0202

Srinath, T., Verma, T., Ramteke, P. W., and Garg, S. K. (2002). Chromium (VI) biosorption and bioaccumulation by chromate resistant bacteria. Chemosphere 48, 427-435. doi: 10.1016/S0045-6535(02)00089-9

Srivastava, S., Agrawal, S., and Mondal, M. (2015). A review on progress of heavy metal removal using adsorbents of microbial and plant origin. Environ. Sci. Pollut. Res. 22, 15386-15415. doi: 10.1007/s11356-015-5278-9

Suman, J., Uhlik, O., Viktorova, J., and Macek, T. (2018). Phytoextraction of heavy metals: a promising tool for clean-up of polluted environment. Front. Plant Sci. 9:1476. doi: 10.3389/fpls.2018.01476

Sun, S., Wang, Y., Zang, T., Wei, J., Wu, H., Wei, C., et al. (2019). A biosurfactantproducing Pseudomonas aeruginosa S5 isolated from coking wastewater and its application for bioremediation of polycyclic aromatic hydrocarbons. Bioresour. Technol. 281, 421-428. doi: 10.1016/j.biortech.2019.02.087

Sun, W., Zhu, B., Yang, F., Dai, M., Sehar, S., Peng, C., et al. (2021). Optimization of biosurfactant production from pseudomonas sp. CQ2 and its application for remediation of heavy metal contaminated soil. Chemosphere 265:129090. doi: $10.1016 /$ j.chemosphere.2020.129090
Talukdar, D., Sharma, R., Jaglan, S., Vats, R., Kumar, R., Mahnashi, M. H., et al. (2020). Identification and characterization of cadmium resistant fungus isolated from contaminated site and its potential for bioremediation. Environ. Technol. Innov. 17:100604. doi: 10.1016/j.eti.2020.100604

Tammam, A., El-Aggan, W., Abou-Shanab, R., and Mubarak, M. (2021). Improved of growth and phytostabilization potential of lead $(\mathrm{Pb})$ in Glebionis coronaria L. under the effect of IAA and GA3 alone and in combination with EDTA by altering biochemical attributes of stressed plants. Int. J. Phytoremediation. 23, 958-968. doi: 10.1080/15226514.2020.1870928

Tang, C. Y., Criddle, Q. S., Fu, C. S., and Leckie, J. O. (2007). Effect of flux (transmembrane pressure) and membranes properties on fouling and rejection of reverse osmosis and nanofiltration membranes treating perfluorooctane sulfonate containing wastewater. Environ. Sci. Technol. 41, 2008-2014. doi: $10.1021 /$ es062052f

Thapa, B., Kumar, A. K. C., and Ghimire, A. (2012). A review on bioremediation of petroleum hydrocarbon contaminants in soil. Kathmandu Univ. J. Sci. Eng. Tech. 8, 164-170. doi: 10.3126/kuset.v8i1.6056

Timková, I., Sedláková-Kaduková, J., and Pristaš, P. (2018). Biosorption and bioaccumulation abilities of actinomycetes/streptomycetes isolated from metal contaminated sites. Separations 5:54. doi: 10.3390/separations5040054

Tripathi, P., Khare, P., Barnawal, D., Shanker, K., Srivastava, P. K., Tripathi, R. D., et al. (2020). Bioremediation of arsenic by soil methylating fungi: role of Humicola sp. strain 2WS1 in amelioration of arsenic phytotoxicity in Bacopa monnieri L. Sci. Total Environ. 716:136758. doi: 10.1016/j.scitotenv.2020.136758

Truu, J., Truu, M., Espenberg, M., Nõlvak, H., and Juhanson, J. (2015). Phytoremediation and plant-assisted bioremediation in soil and treatment wetlands: a review. Open Biotechnol. J. 9, 85-92. doi: 10.2174/ 1874070701509010085

Tsyganov, V. E., Tsyganova, A. V., Gorshkov, A. P., Seliverstova, E. V., Kim, V. E., Chizhevskaya, E. P., et al. (2020). Efficacy of a plant-microbe system: Pisum sativum (L.) cadmium-tolerant mutant and Rhizobium leguminosarum strains, expressing pea metallothionein genes PsMT1 and PsMT2, for cadmium phytoremediation. Front. Microbiol. 11:15. doi: 10.3389/fmicb.2020. 00015

Vajpai, S., Taylor, P. E., Adholeya, A., and Leigh Ackland, M. (2020). Chromium tolerance and accumulation in Aspergillus flavus isolated from tannery effluent. J. Basic Microbiol. 60, 58-71. doi: 10.1002/jobm.201900389

Varjani, S. J., and Upasani, V. N. (2017). A new look on factors affecting microbial degradation of petroleum hydrocarbon pollutants. Int. Biodeterior. Biodegradation 120, 71-83. doi: 10.1016/j.ibiod.2017.02.006

Verma, S., and Kuila, A. (2019). Bioremediation of heavy metals by microbial process. Environ. Technol. Innov. 14:100369. doi: 10.1016/j.eti.2019.100369

Vijayaraghavan, K., and Yun, Y. S. (2008). Bacterial biosorbents and biosorption. Biotechnol. Adv. 26, 266-291. doi: 10.1016/j.biotechadv.2008.02.002

Vithanage, M., Dabrowska, B. B., Mukherjee, A. B., Sandhi, A., and Bhattacharya, P. (2012). Arsenic uptake by plants and possible phytoremediation applications: a brief overview. Environ. Chem. Lett. 10, 217-224. doi: 10.1007/ s10311-011-0349-8

Wang, J., Li, Q., Li, M. M., Chen, T. H., Zhou, Y. F., and Yue, Z. B. (2014). Competitive adsorption of heavy metal by extracellular polymeric substances (EPS) extracted from sulfate reducing bacteria. Bioresour. Technol. 163, 374-376. doi: 10.1016/j.biortech.2014.04.073

Wang, Q., Ye, J., Wu, Y., Luo, S., Chen, B., Ma, L., et al. (2019). Promotion of the root development and $\mathrm{Zn}$ uptake of Sedum alfredii was achieved by an endophytic bacterium Sasm05. Ecotoxicol. Environ. Saf. 172, 97-104. doi: 10.1016/j.ecoenv.2019.01.009

Wang, G., Zhang, Q., Du, W., Ai, F., Yin, Y., Ji, R., et al. (2021). Microbial communities in the rhizosphere of different willow genotypes affect phytoremediation potential in Cd contaminated soil. Sci. Total Environ. 769:145224. doi: $10.1016 /$ j.scitotenv.2021.145224

Wuana, R. A., and Okieimen, F. E. (2011). Heavy metals in contaminated soils: a review of sources, chemistry, risks and best available strategies for remediation. Isrn Ecol. 2011, 1-20. doi: 10.5402/2011/402647

Xiong, Y. W., Li, X. W., Wang, T. T., Gong, Y., Zhang, C. M., Xing, K., et al. (2020). Root exudates-driven rhizosphere recruitment of the plant growth-promoting rhizobacterium Bacillus flexus KLBMP 4941 and its growth-promoting effect on the coastal halophyte Limonium sinense under salt stress. Ecotoxicol. Environ. Saf. 194:110374. doi: 10.1016/j.ecoenv. 2020.110374 
Xu, Z., Tang, M., Chen, H., Ban, Y., and Zhang, H. (2012). Microbial community structure in the rhizosphere of Sophora viciifolia grown at a lead and zinc mine of Northwest China. Sci. Total Environ. 435-436, 453-464. doi: 10.1016/j. scitotenv.2012.07.029

Yadav, S. K. (2010). Heavy metals toxicity in plants: an overview on the role of glutathione and phytochelatins in heavy metal stress tolerance of plants. S. Afr. J. Bot. 76, 167-179. doi: 10.1016/j.sajb.2009.10.007

Yan, L., Van Le, Q., Sonne, C., Yang, Y., Yang, H., Gu, H., et al. (2021). Phytoremediation of radionuclides in soil, sediments and water. J. Hazard. Mater. 407:124771. doi: 10.1016/j.jhazmat.2020.124771

Yan, A., Wang, Y., Tan, S. N., Yusof, M. L. M., Ghosh, S., and Chen, Z. (2020). Phytoremediation: a promising approach for revegetation of heavy metal-polluted land. Front. Plant Sci. 11:359. doi: 10.3389/fpls.2020. 00359

Yang, C., Ho, Y. N., Makita, R., Inoue, C., and Chien, M. F. (2020). Cupriavidus basilensis strain $\mathrm{r} 507$, a toxic arsenic phytoextraction facilitator, potentiates the arsenic accumulation by Pteris vittata. Ecotoxicol. Environ. Saf. 190:110075. doi: 10.1016/j.ecoenv.2019.110075

Yang, S. Z., Jin, H. J., Wei, Z., He, R. X., Ji, Y. J., Lim, X. M., et al. (2009). Bioremediation of oil spills in cold environments: A review. Pedosphere 19, 371-381. doi: 10.1016/S1002-0160(09)60128-4

Yang, Y., Liang, Y., Ghosh, A., Song, Y., Chen, H., and Tang, M. (2015). Assessment of arbuscular mycorrhizal fungi status and heavy metal accumulation characteristics of tree species in a lead-zinc mine area: potential applications for phytoremediation. Environ. Sci. Pollut. Res. 22, 13179-13193. doi: 10.1007/s11356-015-4521-8

Yang, X., Qin, J., Li, J., Lai, Z., and Li, H. (2021). Upland rice intercro pping with Solanum nigrum inoculated with arbuscular mycorrhizal fungi reduces grain $\mathrm{cd}$ while promoting phytoremediation of cdcontaminated soil. J. Hazard. Mater. 406:124325. doi: 10.1016/j.jhazmat.2020. 124325

Yin, K., Wang, Q., Lv, M., and Chen, L. (2019). Microorganism remediation strategies towards heavy metals. Chem. Eng. Sci. 360, 1553-1563. doi: 10.1016/j. cej.2018.10.226

You, Y., Wang, L., Ju, C., Wang, G., Ma, F., Wang, Y., et al. (2021). Effects of arbuscular mycorrhizal fungi on the growth and toxic element uptake of Phragmites australis (Cav.) Trin. ex Steud under zinc/cadmium stress. Ecotoxicol. Environ. Saf. 213:112023. doi: 10.1016/j.ecoenv.2021.112023

Zahoor, M., Irshad, M., Rahman, H., Qasim, M., Afridi, S. G., Qadir, M., et al. (2017). Alleviation of heavy metal toxicity and phytostimulation of Brassica campestris L. by endophytic Mucor sp. MHR-7. Ecotoxicol. Environ. Saf. 142, 139-149. doi: 10.1016/j.ecoenv.2017.04.005
Zand, A. D., Tabrizi, A. M., and Heir, A. V. (2020). The influence of association of plant growth-promoting rhizobacteria and zero-valent iron nanoparticles on removal of antimony from soil by Trifolium repens. Environ. Sci. Pollut. Res. 27, 42815-42829. doi: 10.1007/s11356-020-10252-x

Zanganeh, F., Sepehr, A., and Rohani, A. (2021). Bioaugmentation and bioaugmentation-assisted phytoremediation of heavy metals contaminated soil by a synergistic effect of cyanobacteria inoculation, biochar, and Purtolaca Oleracea. doi: 10.21203/rs.3.rs-439162/v1

Zerizghi, T., Yang, Y., Wang, W., Zhou, Y., Zhang, J., and Yi, Y. (2020). Ecological risk assessment of heavy metal concentrations in sediment and fish of a shallow Lake: a case study of Baiyangdian Lake, North China. Environ. Monit Assess. 192:154. doi: 10.1007/s10661-020-8078-8

Zhang, Y., Liu, J., Zhou, Y., Gong, T., Wang, J., and Ge, Y. (2013). Enhanced phytoremediation of mixed heavy metal (mercury)-organic pollutants (trichloroethylene) with transgenic alfalfa co-expressing glutathione S-transferase and human P450 2E1. J. Hazard. Mater. 260, 1100-1107. doi: 10.1016/j.jhazmat.2013.06.065

Zhang, J., Xu, Y., Cao, T., Chen, J., Rosen, B. P., and Zhao, F. J. (2017). Arsenic methylation by a genetically engineered rhizobium-legume symbiont. Plant Soil 416, 259-269. doi: 10.1007/s11104-017-3207-z

Złoch, M., Kowalkowski, T., Tyburski, J., and Hrynkiewicz, K. (2017). Modeling of phytoextraction efficiency of microbially stimulated Salix dasyclados L. in the soils with different speciation of heavy metals. Int. J. Phytoremediation 19, 1150-1164. doi: 10.1080/15226514.2017.1328396

Conflict of Interest: The authors declare that the research was conducted in the absence of any commercial or financial relationships that could be construed as a potential conflict of interest.

Publisher's Note: All claims expressed in this article are solely those of the authors and do not necessarily represent those of their affiliated organizations, or those of the publisher, the editors and the reviewers. Any product that may be evaluated in this article, or claim that may be made by its manufacturer, is not guaranteed or endorsed by the publisher.

Copyright (c) 2021 Saha, Tiwari, Bauddh and Ma. This is an open-access article distributed under the terms of the Creative Commons Attribution License (CC BY). The use, distribution or reproduction in other forums is permitted, provided the original author(s) and the copyright owner(s) are credited and that the original publication in this journal is cited, in accordance with accepted academic practice. No use, distribution or reproduction is permitted which does not comply with these terms. 